\title{
La crisis de la literariedad y la interpretación literaria
}

\author{
Manuel MALDONADO ALEMÁN \\ Universidad de Sevilla \\ mmaldonado@us.es
}

Recibido: 13 de diciembre de 2010

Aceptado: 24 de enero de 2011

\section{RESUMEN}

Considerando el relativismo en la valoración del fenómeno literario, que ha dado lugar a la llamada crisis de la literariedad, y a partir de una crítica de las concepciones desarrolladas por la hermenéutica clásica y la crítica recepcional empírica acerca de la interpretación, el presente artículo trata de aclarar las relaciones comunicativas que conforman el proceso de interpretación literaria y sus condicionantes.

Palabras clave: Crisis de la literariedad, subjetivismo interpretativo, comprensión e interpretación literarias.

\section{Literariness Crisis and Literary Interpretation}

\begin{abstract}
Considering the relativism in the assessment of the literary phenomenon which has led to the socalled literariness crisis and from the criticism of the conceptions developed by classical hermeneutics and the empirical science of literature about interpretation, the present article tries to clarify the communicative relationships that constitute the process of literary interpretation an its determining factors.
\end{abstract}

Keywords: Literariness Crisis, Interpretative Subjectivism, Literary Comprehension and Interpretation.

SUMARIO: 1 . La crisis de la literariedad. 2. El subjetivismo interpretativo y la hermenéutica. 3 . Entre el constructivismo y el sustancialismo: la crítica recepcional empírica. 4. Comprensión e interpretación literarias.

\section{La crisis de la literariedad}

La comprobación de la precariedad e inestabilidad de los límites de lo literario y de que la dimensión pragmática es imprescindible en su consideración ha motivado el surgimiento de la llamada crisis de la literariedad (Heydebrand 1984; Garrido Gallardo et al. 1987: 9-10; Pozuelo Yvancos 1988: 75). Esta crisis se ha acentuado en las últimas décadas tras dejar de contemplarse el sentido como una dimensión inherente al texto, lo que ha posibilitado el desarrollo de una concepción radicalmente histórica del fenómeno literario. Según esta visión, es 
imposible establecer una definición unívoca y esencial de la literatura ni encontrar unos rasgos lingüísticos que la distingan frente a lo no literario. La demarcación entre literatura y no literatura no puede derivarse sólo de la naturaleza de la dimensión textual, o sea, de unos contenidos o de unas formas lingüísticas fijados normativamente. En rigor, las características textuales no constituyen criterios suficientes ni necesarios para determinar lo literario, pues los textos no son literarios por sí mismos, sino sólo con relación a un contexto comunicativo determinado y en función de unos actantes específicos ${ }^{1}$.

La perspectiva histórica cuestiona que la literariedad, entendida como el conjunto de características que dan especificidad literaria a la obra, constituya una propiedad intrínseca, o sea, formal o estructural, de la propia obra, dado que esa propiedad necesita de un lector que la actualice. En consecuencia, en esta perspectiva deja de buscarse en los mecanismos verbales y estructurales del texto la causa de la literariedad, y se considera determinante en la valoración literaria de cualquier texto la actuación del receptor y la situación de recepción, así como también las circunstancias sociohistóricas que permiten tal valoración. Incluso se acepta la posibilidad de que un texto considerado literario no se diferencie estructuralmente de uno no literario. Pues no son sus propiedades intrínsecas lo que hace de un texto una obra literaria, sino el modo en el que el receptor lo considera. La cualidad de literario, en suma, es el resultado de unos procesos específicos de comprensión.

La consideración de un texto como literario depende, sobre todo, de unos valores, normas o motivaciones sociales y culturales vigentes en una sociedad dada en un momento determinado, y de un lector que siguiendo esas normas y convenciones actualiza de manera literaria la estructura lingüístico-material del texto. Por esa razón, el texto al que se le ha atribuido la condición de literario no es literario en un sentido esencialista o inmanente, a modo de cualidad intemporal y universal; antes al contrario, al cambiar las circunstancias de atribución, bien podría perder las características estéticas asignadas. O sea, la literariedad es, en lo fundamental, una dimensión cambiante histórica y culturalmente, que aparece determinada por factores cognitivo-individuales y sociales (Meutsch 1984: 109; Rusch 1993: 173).

No obstante, pese a que la asignación a un texto de la cualidad de literario depende de un sujeto, no por ello esa atribución es necesariamente subjetiva o realizada a capricho. La asignación del predicado " $X$ es literario" en modo alguno

\footnotetext{
${ }^{1}$ Así, por poner un ejemplo, se constata una y otra vez que la ficcionalidad no puede actuar como criterio de delimitación suficiente por cuanto no es exclusiva del texto artístico ni otorga por sí misma la condición estética a una obra literaria. Sobre todo en épocas antiguas y medievales se han escrito obras a las que originariamente no se les atribuyeron, ni por sus autores ni por sus lectores, un carácter ficcional, pero que sin embargo hoy en día son consideradas literarias. Incluso, como ocurre en la literatura del siglo XX, numerosas obras incluyen textos de naturaleza no ficcional -partes meteorológicos, clasificaciones de equipos de fútbol, fragmentos de guías telefónicas, informes estadísticos, recetas, eslóganes publicitarios, etcétera- que son integrados en un proceso de comunicación literaria.
} 
ha de ser arbitraria, dado que aparece condicionada por distintos factores: la competencia y conocimientos literarios del lector, sus intenciones y motivaciones, la situación de comunicación, las propias instituciones literarias y sus participantes (escritores, editores, críticos, etcétera), y especialmente las convenciones que el lector ha asimilado en el transcurso de su socialización literaria y que actualiza durante la recepción.

Considerando este relativismo en la valoración del fenómeno literario, la literatura puede concebirse como un modo específico de interacción social y de comunicación, como un fenómeno complejo que, al estar integrado en una amplia red de acciones sociales, no deberá ser considerado y valorado exclusivamente a partir de la inmanencia textual, o sea, indicando sus propiedades formales o estructurales, sino de un modo pragmático y funcional, que tenga en cuenta las relaciones que establecen los usuarios con el texto.

Desde esta perspectiva, y a partir de una crítica de las concepciones desarrolladas por la hermenéutica clásica y la crítica recepcional empírica acerca de la interpretación, se tratarán de aclarar a continuación las relaciones comunicativas que conforman el proceso de interpretación literaria y sus condicionantes.

\section{El subjetivismo interpretativo y la hermenéutica}

En el siglo XX, la hermenéutica ${ }^{2}$ parte de un rechazo categórico de la exigencia de legitimación empírica de la actividad crítico-literaria ante la presunta falta de compatibilidad entre la naturaleza histórica del sujeto y del objeto de estudio de las ciencias humanas, por un lado, y la metodología empírica, por otro. El escepticismo respecto a todo proceder empírico va a suponer que tanto la observación como la experiencia sean consideradas impropias para el análisis del fenómeno literario ${ }^{3}$, por lo que sobre la base de la dicotomía decimonónica entre ciencias de la naturaleza y ciencias del espíritu se va a justificar un riguroso dualismo metodológico, que el posterior desarrollo de la hermenéutica convertirá en un hecho incuestionable.

Las diferentes corrientes que configuran la hermenéutica vienen a coincidir a este respecto, aunque con diferencia de matiz, esencialmente en lo mismo: las ciencias naturales y del espíritu muestran una disparidad antinómica de metodología y objetos de investigación. Mientras las primeras se ocupan de fenómenos o

\footnotetext{
${ }^{2}$ Dado que una crítica pormenorizada de la hermenéutica en sus múltiples vertientes no es objetivo de este artículo, se considera conveniente centrar la atención en un análisis crítico de la denominada hermenéutica idealista, es decir, la representada principalmente por W. Dilthey y H.-G. Gadamer. No obstante, ello no es óbice para que, en lo fundamental, los argumentos críticos expuestos puedan se extendidos a otras corrientes hermenéuticas.

3 La desconfianza de la metodología empírica llegará incluso a manifestarse entre los investigadores que reconocen la necesidad de fundamentar empíricamente los estudios literarios. Éstos alegan la ineficacia del proceder empírico para dilucidar lo que ellos consideran el objetivo esencial de la labor crítico-literaria, o sea, la averiguación del sentido único e invariable supuestamente existente en la obra. Véase CONRADY (1974: 16).
} 
hechos ahistóricos, pertenecientes al ámbito de la naturaleza, con la finalidad de descubrir y explicar las relaciones causales existentes entre ellos y formular las leyes y principios generales a los que están sometidos, el objeto de las ciencias del espíritu es el propio ser humano, que se distingue por su historicidad, y las múltiples expresiones o significaciones por él constituidas. A diferencia de las ciencias naturales, las ciencias del espíritu no pretenden descubrir regularidades generales, sino, muy al contrario, su objetivo es dilucidar tanto el sentido específico y único como el valor relevante de las acciones humanas y de sus resultados que, al contrario del objeto de las ciencias experimentales, son investigados como individualidades. A esta dualidad de objetos corresponde necesariamente una dualidad categórica de métodos, que W. Dilthey (1900: 144) resumió con claridad en una sola frase: "Die Natur erklären wir, das Seelenleben verstehen wir". Por cuanto las ciencias humanas se refieren a fenómenos de la 'experiencia interior', éstos no pueden ser explicados sino comprendidos. De este modo, en estricta oposición a los procedimientos de la explicación causal empleados en las ciencias experimentales, la hermenéutica establece la comprensión descriptiva como método específico de aprehensión de las manifestaciones del espíritu ${ }^{4}$.

No obstante, la determinación de la hermenéutica moderna de establecer la comprensión como el método de conocimiento de las humanidades no puede considerarse como continuación o desarrollo ulterior de la hermenéutica tradicional, tal como algunos estudiosos han estimado (Ebeling 1959; Gadamer 1986). La hermenéutica, en sus comienzos, no fue concebida ni como filosofía ni como ciencia, sino simplemente como un arte, como el arte de la interpretación de textos ${ }^{5}$, y

\footnotetext{
${ }^{4}$ Epistemológicamente, la comprensión como modelo de conocimiento encuentra su razón de ser a raíz del rechazo de la hermenéutica del modelo epistemológico cartesiano, por estimarlo inadecuado para el conocimiento del objeto de las ciencias humanas. R. Descartes, fascinado por los importantes logros de las ciencias físico-matemáticas, sólo reconoce dos fuentes de conocimiento: por un lado, el sujeto pensante (la res cogitans) y, por otro, el objeto exterior (la res extensa). Ambos polos, el subjetivo y el objetivo, radicalmente distintos y heterogéneos, están escindidos y enfrentados entre sí. La posibilidad de coincidencia entre las dos sustancias la otorga Dios; sólo éste permite, según Descartes, que el sujeto alcance el conocimiento del mundo exterior, sin que se dé la posibilidad de que en ese proceso intervenga una tercera fuente del conocer, de hecho inexistente, sea ésta un saber recibido o heredado, una tradición cultural, o bien, la comprensión del pasado histórico. Por el contrario, la hermenéutica, estableciendo como uno de sus pilares básicos la superación de la estricta dualidad cartesiana, propondrá sustituir la situación de enfrentamiento entre sujeto y objeto por una relación de mediación de tipo circular (ACOSTA 1978: 29), en la que las dos realidades, aparentemente diferentes, se interrelacionan y se remiten, e incluso se transforman, mutuamente, o sea, circularmente, en un mismo acto, generando un proceso de comprensión o conocimiento.

${ }^{5}$ El término hermenéutica aparece en la edad moderna en sustitución de la expresión ars interpretandi de la tradición humanista $\mathrm{y}$, según los testimonios documentales de que se disponen, fue utilizado por primera vez a mediados del siglo XVII en las obras de Johann C. Dannhauer, profesor luterano de Retórica y Teología (véase Hermeneutica sacra sive methodus exponendarum sacrarum litterarum, Estrasburgo, 1654). El término hermenéutica, de origen griego, fue tomado del título de uno de los tratados de lógica que componen el Organon aristotélico y pasó a indicar la transformación de la doctrina de la significación lógica de las enunciaciones en un procedimiento
} 
se dividía en una hermenéutica jurídica para la interpretación de los textos legales, una hermenéutica filológica para la interpretación de las grandes obras literarias, en especial las del Clasicismo grecolatino, y una hermenéutica teológica para la exégesis de las Sagradas Escrituras. Con su ayuda se trataba de descubrir, comprender y explicitar correctamente la significación profunda que se suponía oculta detrás de las palabras de los textos religiosos, jurídicos y estéticos. Su finalidad consistía en diferenciar el "verum sensum a falso" (J. C. Dannhauer) y se utilizaba el término "intellegere" no en oposición a "explicare", sino con el sentido perfectivo de 'haber entendido'. O sea, la comprensión no designaba el proceso de la interpretación, es decir, no era un método de aprehensión; más bien, indicaba el resultado de una interpretación adecuada que se ha alcanzado tras aclarar los espacios ambiguos y contradictorios del texto. La hermenéutica se consideró así, originariamente, como una técnica concreta con una función auxiliar para la constatación del sentido, y no como una metodología general y universal para la reconstrucción o reproducción de ese sentido.

En la hermenéutica moderna, cuyos inicios se remontan al Romanticismo, concretamente a la primera mitad del siglo XIX cuando F. D. E. Schleiermacher fundamenta el sentido tradicional de la ars interpretandi (Kunst der Auslegung) en un arte del comprender (Kunst des Verstehens), el significado del término comprensión sufre un cambio radical. La comprensión es entendida ahora, siguiendo la concepción de Schleiermacher, como un procedimiento adivinatorio y comparativo de reconstrucción, que, apoyándose en un conocimiento gramatical e histórico del texto, está dirigido a conseguir la compenetración (Einfühlung) con el autor y su psicología, y por extensión analógica con su obra. La comprensión, por tanto, se evidencia como el arte de la adivinación, efectuada mediante la identificación o congenialidad con el autor de la obra. Su finalidad es comprender al autor mejor de lo que él se ha comprendido a sí mismo, eliminando para ello los elementos extraños que puedan interponerse entre él y su intérprete, y adquiriendo, además, conciencia clara de los condicionantes involuntarios que intervienen en el acto de la producción artística. De este conocimiento profundo habría de derivarse una comprensión plena del texto ${ }^{6}$. La intención de Schleiermacher, pues, una vez superada la distinción entre hermenéutica sacra y hermenéutica profana, era crear, mediante la reducción de la hermenéutica al ámbito de la comprensión misma, una hermenéutica universal que sirviera de fundamento a todo acto de comprensión.

Pese al importante cambio conceptual producido, con Schleiermacher la hermenéutica no pasa de ser un procedimiento concreto con el limitado cometido de facilitar la comprensión correcta de una afirmación ajena, especialmente si es escrita (Schleiermacher 1977: 71). En su propuesta, el proceder hermenéutico no llega a constituirse en una teoría o metodología de la interpretación y comprensión

para la interpretación de textos. Véase JAEger (1974); BRINKMANN (1980); PuglieSE (1988); RUSTERHOLZ (1990); JAPP (1992); BRENNER (1998: 5 y ss.).

${ }^{6}$ Véase Schleiermacher (1977); SzONDI (1975); Birus (1982); BrenNer (1998: 39 y ss.); LAU (1999: 272 y ss.). 
de los fenómenos histórico-sociales. La verdadera transformación de la hermenéutica la lleva a efecto W. Dilthey, quien años después, tras el surgimiento del positivismo y el historicismo, emprende su fundamentación y generalización como metodología específica de las ciencias del espíritu. Es a partir de él, cuando la hermenéutica, ya en su calidad de teoría de la interpretación, pasa a ser entendida de modo general como "reflexión sobre los principios fundamentales y los condicionamientos generales que determinan la comprensión y formulación de esta comprensión por medio del lenguaje" (Acosta 1989: 57).

La preocupación fundamental de Dilthey consiste en otorgar legitimidad científica y autenticidad objetiva al conocimiento históricamente condicionado, obtenido por las ciencias humanas. Su finalidad es elaborar un método que permita acceder a interpretaciones objetivamente válidas y que confiera, de este modo, un fundamento científico a las ciencias del espíritu. Ello posibilitará que las ciencias humanas adquieran el mismo reconocimiento del que por entonces gozaban las ciencias de la naturaleza.

Tras superar una primera fase en la que se mantuvo fiel al psicologismo, Dilthey (1900: 319) concibe la hermenéutica como "[das] kunstmäßige Verstehen von dauernd fixierten Lebensäußerungen". Entiende la comprensión como un proceso, "in welchem aus sinnlich gegebenen Äußerungen seelischen Lebens dieses zur Erkenntnis kommt" (Dilthey 1900: 318). El fundamento de la comprensión ya no es la psicología, sino la historia: "Der Mensch erkennt sich nur in der Geschichte, nie durch Introspektion" (Dilthey 1910: 279). La comprensión deja de ser un acto de aprehensión inmediata de lo psíquico, para constituirse en una forma de conocimiento que se efectúa a través de la intervención de los signos exteriorizados, esto es, mediante la expresión u objetivación de sentido (Ausdruck) que, al igual que la conciencia individual del intérprete, está enraizada en un contexto histórico concreto que condiciona su aprehensión. La comprensión se manifiesta, así, como un fenómeno relativizado por la historicidad, orientado a la reproducción (Nachbildung) de las manifestaciones de vida de otros sujetos en virtud de la comunidad existente entre los individuos (Dilthey 1910: 141).

La comprensión como reproducción, sin embargo, no es un acto que culmine en el conocimiento vivencial de lo particular y lo concreto; antes bien, su realización completa exige que la experiencia de lo singular conduzca, por medio de un procedimiento inductivo, a la aprehensión de la totalidad del objeto de conocimiento, y que este proceso se complete con un regreso a la vivencia de lo concreto, pues lo particular requiere para su profundo entendimiento los conocimientos otorgados por la comprensión de lo general. La comprensión se configura, de este modo, como un proceso de naturaleza circular: las características individuales de un texto sólo son inteligibles a partir de la totalidad de la obra, mientras que ésta sólo se puede comprender a través de sus peculiaridades particulares. En palabras de Dilthey (1900: 334): "Aus dem Einzelnen das Ganze, aus dem Ganzen doch wieder das Einzelne. Und zwar das Ganze eines Werkes fordert Fortgang zur Individualität (des Urhebers), zur Literatur, mit der sie im Zusammenhang steht". Esta circularidad determina la actividad comprensiva de las ciencias del espíritu y 
configura, en suma, su propia estructura; una peculiaridad que, por otra parte, diferencia sustancialmente las ciencias humanas de las ciencias de la naturaleza.

La finalidad de este proceso comprensivo de naturaleza circular es obtener unos resultados cognoscitivos universalmente válidos que aseguren una interpretación objetiva y completa (Dilthey 1900: 317 y 320). La garantía de esta objetividad la otorga la conciencia histórica, instancia nacida de la reflexión sobre las limitaciones de la conciencia individual y que permite superar, si el sujeto, en cuanto individuo aislado, la adquiere, las dificultades impuestas al conocimiento por la condición subjetiva del individuo. De aquí se infiere que toda labor interpretativa, si en realidad quiere desempeñar eficazmente su cometido, debe conseguir la eliminación de la disparidad sincrónica y diacrónica existente entre el intérprete y lo interpretado. Es decir, se exige que la hermenéutica garantice, merced a la superación de los condicionantes históricos y prejuicios subjetivos que relativizan la perspectiva del individuo intérprete, un conocimiento comprensivo de índole científica que excluya la arbitrariedad y la subjetividad interpretativas.

Con la intención de hacer viable tal pretensión, Dilthey reduce las diferentes hermenéuticas existentes (la filológica, la jurídica y la teológica) a una única hermenéutica filosófica, general y fundamental, que ya no es una simple técnica auxiliar de interpretación, toda vez que aspira a constituirse en una auténtica metodología de conocimiento propia de todas las ciencias humanas (Dilthey 1900: 328). Esta ciencia hermenéutica, basándose en la confluencia de los conceptos de experiencia vivida (Erleben), expresión (Ausdruck) y comprensión (Verstehen) (Dilthey 1900: 87), y mostrándose acorde con el objeto histórico de las ciencias del espíritu, permitiría, en definitiva, fundamentar adecuadamente las humanidades y erigirlas en ciencias objetivas.

Sin embargo, la hermenéutica de Dilthey, por cuanto persevera en una concepción de la comprensión basada en la transposición de las propias vivencias subjetivas en las vivencias ajenas, no logra superar, como pretende, el psicologismo. La ausencia de un método racional de control de la intervención de las vivencias subjetivas en el proceso comprensivo supone que sean, en rigor, la intuición y la certeza subjetiva los criterios de la pretendida cientificidad de los resultados de la actividad interpretativa. Dilthey no advierte que no es posible derivar del simple análisis de los componentes de la comprensión una metodología reguladora de la interpretación textual. Por otra parte, a pesar de que Dilthey establece la hermenéutica como disciplina filosófica en estricta oposición a la metodología de las ciencias de la naturaleza, al determinar su carácter científico acaba orientándose paradójicamente, de manera implícita, en el ideal de objetividad establecido en su época por las ciencias experimentales. Como consecuencia de ello, la exigencia metodológica de objetividad, impuesta finalmente por Dilthey a todo conocimiento comprensivo, restringe en gran medida la validez del principio de relatividad histórica en el que éste había 
basado la peculiaridad tanto del objeto como de la actividad cognoscitiva de las ciencias del espíritu?

H.-G. Gadamer (1960: 246) sitúa el origen de semejante incongruencia en el hecho de que Dilthey no logra liberarse completamente del cartesianismo epistemológico y que, en consecuencia, no considera determinante la historicidad de la experiencia histórica. De aquí deduce Gadamer la necesidad de renovar la hermenéutica a partir de la dilucidación de las condiciones subyacentes en todo acto de comprensión, de manera que se dé solución a las deficiencias propias del razonamiento de Dilthey y se supere el modelo cartesiano.

La historicidad de la comprensión constituirá, por consiguiente, el tema central de la reflexión hermenéutica de Gadamer, cuya finalidad no consistirá en liberar la actividad investigadora de su condicionalidad histórica en aras de unos resultados objetivos, sino, muy al contrario, en cerciorarse positivamente de la significación de semejante limitación. El interés ya no está centrado en la problemática de la interpretación correcta; ahora, más bien, se pondrá énfasis en analizar las condiciones de posibilidad y las características intrínsecas que configuran las limitaciones de la actividad comprensiva. En definitiva, como indica el propio Gadamer (1960: 300), el objetivo de su modelo hermenéutico no estriba en desarrollar un método de la comprensión, sino en aclarar las condiciones propias de la actividad comprensiva. Este rechazo de cualquier forma de procedimiento científico o metodológico, estrictamente coherente con la convicción del eminente filósofo de que el conocimiento hermenéutico posee una objetividad del todo distinta a la expresada por las ciencias modernas (Gadamer 1960: 246), va a caracterizar, en lo esencial, su concepción de la hermenéutica. En la primera página de la introducción a su obra fundamental Wahrheit und Methode, ya lo expone con claridad:

Das hermeneutische Phänomen ist ursprünglich überhaupt kein Methodenproblem. Es geht in ihm nicht um eine Methode des Verstehens, durch die Texte einer wissenschaftlichen Erkenntnis so unterworfen werden, wie alle sonstigen Erfahrungsgegenstände. Es geht in ihm überhaupt nicht in erster Linie um den Aufbau einer gesicherten Erkenntnis, die dem Methodenideal der Wissenschaft genügt [...] (Gadamer 1960: 1).

Este distanciamiento deliberado de la exigencia de la ciencia moderna de aplicar una metodología científica no va a suponer, sin embargo, la renuncia a la pretensión de descubrir por medio de los actos cognoscitivos la verdad del sentido implantado en la obra literaria. Pues, también en este caso "[es geht] um Erkenntnis und um Wahrheit auch hier. Im Verstehen der Überlieferung werden nicht nur Texte verstanden, sondern Einsichten erworben und Wahrheiten

${ }^{7}$ A. O. Pugliese (1988: 35-36), estableciendo una analogía comparativa entre la fundamentación diltheyana de la metodología hermenéutica y la fundamentación epistemológica de las ciencias naturales efectuada por I. Kant, atribuye a la inexistencia en las humanidades de una tradición científica mínimamente consolidada la razón por la que las pretensiones de Dilthey no consiguieron el resultado ambicionado. 
erkannt“ (Gadamer 1960: 1). La verdad, en el ámbito de la experiencia estética, se alcanza, no obstante, a través de un conocimiento inmediato y no en virtud de la elaboración de relaciones de correspondencia o de adecuación. En este sentido, en clara alusión al concepto de verdad de M. Heidegger, quien la concibe como un "Sichentdecken", Gadamer (1960: 491) hace referencia a un "Sichtdarstellen als das wahre Sein des Kunstwerks" en el proceso de la comprensión.

En definitiva, en congruencia con sus propios criterios, Gadamer (1960: 29) establece programáticamente el principio verdad contra método como postulado fundamental del procedimiento hermenéutico: "der Wahrheitssanspruch geisteswissenschaftlicher Erkenntnis [ist nicht] unter das ihm wesensfremde Maß des Methodendenkens der modernen Wissenschaft [zu stellen]"8. Consecuentemente, adopta como punto de partida de su hermenéutica filosófica la concepción heideggeriana de la comprensión, según la cual ésta no es un método de conocimiento, sino "ein fundamentales Existenzial" (Heidegger 1957: 143), o sea, el modo de ser de la existencia humana o Dasein, que al estar abocada a un "estar-siempre-en-elmundo" se manifiesta determinada por la temporalidad y la historicidad. Concretando a Heidegger, Gadamer concibe la comprensión como una actividad que se produce sobre la base de un diálogo entre el pasado y el presente, entre texto e intérprete, en cuyo transcurso aquél 'responde' a las preguntas que éste, desde su situación histórica concreta y guiado por sus propios intereses y preocupaciones, le plantea. Las respuestas del texto dependerán del tipo de preguntas que se le dirija, las cuales están supeditadas de una u otra manera a los prejuicios con los que el sujeto se acerca a la obra.

En contraposición a la tradición impuesta por la Ilustración, en este modelo dialógico, el prejuicio, más que un concepto negativo, es un factor positivo, toda vez que constituye, al proporcionar un preconocimiento intuitivo de aquello que se va a comprender, la base de toda comprensión: "'Vorurteil' heißt also durchaus nicht notwendig falsches Urteil. In seinem Begriff liegt, daß es positiv und negativ gewertet werden kann" (Gadamer 1960: 275). El concepto de prejuicio, pues, no posee ninguna connotación de valor; sólo indica su anterioridad con respecto a un juicio definitivo que bien puede ser verdadero o falso. El prejuicio es así condición necesaria para que pueda darse el juicio. Los prejuicios crean un primer contexto de sentido en el que el intérprete encuadra el texto. De este modo, ya desde su comienzo, la lectura interpretativa de la obra se ve orientada, pero también ineludiblemente condicionada, por una precomprensión general de su totalidad, sin la cual, asegura Gadamer, el intérprete no podría entenderla. Con el desarrollo, a través del proceso de la interpretación, de este esbozo previo de comprensión, se revisan y, dado el caso, se modifican los prejuicios y preconcepciones tácitas para dar paso a una comprensión explícita. Los prejuicios que finalmente contiene la comprensión efectiva están arraigados en un marco histórico intersubjetivo que los justifica y por ello son

\footnotetext{
${ }^{8}$ La caracterización del conocimiento hermenéutico como un conocimiento no metódico no es óbice, sin embargo, para que Gadamer sí se someta al 'pensamiento metódico', o sea, a las 'reglas implícitas' del análisis filológico, cuando interpreta textos de Hölderlin. Véase GADAMER (1967: 45 y ss.).
} 
necesariamente verdaderos. De éstos hay que diferenciar los prejuicios falsos que, al fundamentarse en la subjetividad, son negativos y efímeros.

Condición necesaria para que pueda desarrollarse el proceso dialógico de la comprensión es una actitud franca y sincera por parte del intérprete, así como una disposición a la revisión de las ideas preconcebidas, que proteja la interpretación. La garantía de una verificación o, en su caso, rectificación correcta de los prejuicios, que evite un subjetivismo ilimitado, la otorga la tradición, una instancia perdurable de la que emana la intersubjetividad que legitima tanto las preconcepciones verdaderas como la coherencia del sentido que finalmente ha sido otorgado al texto. En la tradición se encuentra inmersa y sometida a su influencia no sólo la obra, sino también, como ser histórico, el sujeto intérprete con todas sus precomprensiones y manifestaciones. La tradición unifica las distintas perspectivas históricas y va formando, de modo paulatino y continuo, la comunidad. Así, gracias a ella, se puede alcanzar la confluencia del horizonte o perspectiva de suposiciones que el intérprete establece con el horizonte en el que se ubica la obra. Esta fusión de horizontes, sin la que no habría ninguna posibilidad de comprensión, no significa la suspensión o abandono de una de las perspectivas sino, más bien, la integración dialéctica de ambas en un único horizonte. En el transcurso de la penetración en el horizonte del texto, el sujeto intérprete realiza nuevas experiencias que, al introducirlas en su propio horizonte, originan un cambio de sus perspectivas individuales $y$, por ende, una mejor comprensión de la obra y de sí mismo. Para Gadamer, en suma, la comprensión no es traslación o transposición de perspectivas históricas, sino integración de lo extraño en lo conocido. "Daher ist Verstehen kein nur reproduktives, sondern stets auch ein produktives Verhalten" (Gadamer 1960: 301).

Precisamente en la ausencia de defección en el transcurso de la fusión de horizontes se sustenta la estructura circular que el proceso de la comprensión también posee para Gadamer. Si bien se revisa y se modifica parcialmente la precomprensión de la que parte el sujeto intérprete, ésta no llega, en rigor, a ser abandonada: la comprensión del texto siempre quedará determinada por el movimiento de anticipación de sentido de la precomprensión (Gadamer 1960: 298). En cualquier caso, dado que sin la existencia previa de prejuicios verdaderos no se alcanzaría un conocimiento comprensivo efectivo, al finalizar la interpretación el sujeto encontrará en el texto una confirmación de su esbozo intuitivo de comprensión. Por esta razón, Gadamer asevera que la interpretación una vez concluida no implica la superación del círculo hermenéutico sino, muy al contrario, su realización expresa: éste acabará siempre prevaleciendo, pues los prejuicios que habían servido de punto de partida aparecerán de nuevo, al menos parcialmente, en la interpretación obtenida.

La inevitable condición circular de toda actividad de comprensión se fundamenta en la propia historicidad de ésta. El sujeto puede comprender fenómenos históricos sólo porque él mismo y todos sus actos cognoscitivos están inmersos en la historia y se muestran relativizados hasta cierto grado precisamente por ella. La historicidad posibilita el acto de conocimiento, pero a la vez lo condiciona ineludiblemente: si bien predetermina la comprensión, sin ella no podría existir ningún 
tipo de actividad comprensiva. Aquí radica precisamente para Gadamer lo positivo y productivo del insuperable círculo hermenéutico, que según él, como se ha visto, no es un círculo metódico o formal, sino en lo esencial el medio de la descripción de los condicionantes de la estructura ontológica de la comprensión (Gadamer 1960: 298-299).

A pesar de los grandes esfuerzos realizados por la hermenéutica filosófica de Gadamer al objeto de legitimar la intersubjetividad de los actos cognoscitivos del sujeto intérprete, que en suma garantizaría el acercamiento al sentido verdadero del texto, su concepción de la comprensión difícilmente puede ocultar un subjetivismo latente. Gadamer caracteriza metafóricamente la comprensión como la fusión de horizontes aparentemente contrapuestos: ante la "relación de tensión" existente entre la perspectiva de pasado, en la que está ubicado el texto, y el presente, el intérprete esboza desde su posición un horizonte histórico en el que sitúa la obra, que habrá de confluir con su propio horizonte en el proceso de la comprensión. Sin embargo, la ausencia de un procedimiento metodológico que controle la elaboración desde el presente del esbozo del horizonte histórico provoca que esa elaboración no pase de ser una operación subjetiva, relativizada por las perspectivas particulares del individuo intérprete. Ante la falta de un método intersubjetivo de control que permita deslindar los prejuicios falsos de los verdaderos, el intérprete siempre podrá llegar a una autoconfirmación de las preconcepciones subjetivas que inician el proceso comprensivo. Este subjetivismo conducirá a que la comprensión quede reducida a un proceso en cuyo transcurso el sujeto intérprete medie consigo mismo. O sea, debido a que se fundamenta en prejuicios, y ante la imposibilidad de superar esa condición, la interpretación de la obra literaria sólo puede configurarse como un acto situacional e inconcluso, sometido a continuos cambios y transformaciones. La aprehensión de la totalidad del sentido verdadero de un texto o de una obra artística nunca llega a alcanzarse: es un proceso sin fin (Gadamer 1960: 303). De cada nuevo contexto histórico podrán surgir nuevos significados sin que nunca llegue a conocerse la obra plena y definitivamente.

Gadamer intenta suplir mediante el recurso a la tradición la falta de una metodología que supere el subjetivismo latente en el acto de la interpretación literaria. Eleva la tradición a la categoría de autoridad incuestionable y le otorga funciones de control de la coherencia de la comprensión: "Das durch Überlieferung und Herkommen Geheiligte hat eine namenlos gewordene Autorität" (Gadamer 1960: 285). La tradición crea una continuidad unificadora que permite superar la distancia histórica entre el pasado del objeto de conocimiento y el presente del sujeto de la interpretación. Su presencia es absoluta: el pasado sólo se puede actualizar como tradición, mientras que en el presente ésta se manifiesta en los prejuicios que determinan las vías por las que ha de discurrir la comprensión. De aquí que en la comprensión de todo texto intervenga continuamente el pasado, esto es, la influencia de la historia de los prejuicios verdaderos que Gadamer llama historia efectual. Precisamente por ello, porque la comprensión del sujeto está condicionada una y otra vez por los prejuicios procedentes de la historia efectual del texto que aquél quiere comprender, su comprensión derivará necesariamente en una reconfirma- 
ción: si Gadamer exige que sólo los prejuicios del intérprete que se deriven de la tradición pueden ser considerados positivos o verdaderos, mientras que el resto son negativos o falsos, los prejuicios que en realidad van a ser justificados son aquellos que ya han sido legitimados previamente a lo largo de la historia efectual del texto. La verdad, aunque mediatizada por los prejuicios, es legada única y exclusivamente por la tradición. En rigor, por tanto, a falta de una metodología adecuada, la comprensión textual no configura un acto productivo controlado intersubjetivamente, sino que es un simple "Einrücken in ein Überlieferungsgeschehen" (Gadamer 1960: 295). Todo nuevo intérprete de la obra tratará de someterse de manera acrítica a la autoridad de la tradición, para así encontrar en ella el sentido "verdadero" del texto. En consecuencia, la verdad del texto quedará reducida a su historia, es decir, al sentido que hasta ahora le ha sido otorgado y que se le seguirá otorgando en el futuro.

El ostensible sustancialismo que esta postura entraña se hace más notorio cuando Gadamer introduce el concepto de lo clásico como modo de manifestación de la tradición. Lo clásico es aquello que resiste toda crítica histórica y cuya validez es intemporal, "weil seine geschichtliche Herrschaft, die verpflichtende Macht seiner sich überliefernden und bewahrenden Geltung, aller historischen Reflexion schon vorausliegt und sich in ihr durchhält" (Gadamer 1960: 292). Por ello, todo lo que de él provenga ha de ser preservado con fervor.

Este marcado sustancialismo, hacia el que deriva la hermenéutica filosófica de Gadamer, es una necesidad teórica para que pueda efectuarse el proceso de comprensión descrito: sin una magnitud sustancial que garantice la compatibilidad de los distintos horizontes, la fusión de éstos en la comprensión no podría tener lugar. Pero el dilema para Gadamer estriba en que con ello abandona el postulado del relativismo histórico, en el que había fundamentado su concepción. Así, a modo de ejemplo, la suposición sustancialista de una esencia atemporal del concepto de 'patria' garantiza, ciertamente, la confluencia de horizontes en el transcurso de la interpretación del poema de Hölderlin Der Tod fürs Vaterland, pero también ignora que un mismo concepto puede tener distintos sentidos en diferentes contextos históricos. El poema de Hölderlin fue interpretado, en efecto, por la crítica literaria alemana en la época de la Primera y Segunda Guerra Mundial desde una perspectiva nacional chovinista, sin tener en cuenta que Hölderlin utilizó el término 'patria' en el contexto específico de la Revolución Francesa. A este respecto, habría que preguntarse qué tradición tendría que ejercer de esencia unificadora de los distintos horizontes históricos y cuál de ellas garantizaría la coherencia de la comprensión.

La hermenéutica filosófica no puede dar respuesta a esta cuestión ya que persevera en el postulado de la existencia en los textos de un sentido atemporal y verdadero que habría que tratar de descubrir desde el trasfondo de una única tradición legítima. La hermenéutica de Gadamer se fundamenta en el supuesto de que la historia es un continuo unitario sin interrupciones o rupturas; y que la tradición sólo puede configurarse como una corriente homogénea a la que pertenecerían todas las grandes obras de la literatura, que verían así garantizadas eternamente su presencia y validez. Gadamer parece ignorar a este respecto que la determinación de lo que es o no váli- 
do se fundamenta en un proceso de decisión social, desarrollado dentro de unas coordenadas espacio-temporales muy concretas, cuya vigencia de ningún modo es absoluta. Es un grupo social determinado, y no una esencia universal abstracta, la instancia que eleva convencionalmente algunas obras al rango de lo 'válido', pero también desestima otras que pasan al más completo olvido.

El sustancialismo, en el que inevitablemente se fundamenta la concepción de Gadamer, adopta en el seno de la hermenéutica clásica otras modalidades aún más exacerbadas. Una de las que ha ejercido una notable y pertinaz influencia, sobre todo en la crítica literaria alemana tras la Segunda Guerra Mundial, es la denominada interpretación inmanente o método intrínseco. Este método se propone determinar la obra literaria en su esencia. La interpretación inmanente no concibe la obra como un producto histórico o social, sino como una entidad autónoma poseedora de una verdad propia e inmutable que sólo puede ser captada de manera fiel por la interpretación hermenéutica, si ésta, a fin de prevenir el relativismo histórico o cultural, se circunscribe exclusivamente a la realidad inmanente del texto y se abstiene de emitir juicios de valor. Pues lo que en rigor importa "ist das Wort des Dichters, das Wort um seiner selbst willen, nichts was irgendwo dahinter, darüber oder darunter liegt. [...] daß wir begreifen, was uns ergreift, das ist das eigentliche Ziel aller Literaturwissenschaft" (Staiger 1953: 11). La llamada diferencia hermenéutica, es decir, la escisión entre el sujeto (el intérprete) y el objeto (el texto), sólo puede ser superada, según el criterio del método intrínseco, si la fascinación emocional que lo estético provoca en el sujeto se somete a un proceso racional de conocimiento comprensivo, que utilizando el procedimiento del círculo hermenéutico asegure la neutralidad del intérprete y convierta el componente subjetivo originario en un factor 'objetivo'. La superación de la diferencia hermenéutica otorgaría, en definitiva, a la interpretación inmanente un carácter 'científico':

In der Vorerkenntnis des ersten Gefühls und in dem Nachweis, daß es stimmt, erfüllt sich der hermeneutische Zirkel der Interpretation [...]. Bin ich auf dem rechten Weg, hat mein Gefühl mich nicht getäuscht, so wird mir bei jedem Schritt, den ich tue, das Glück der Zustimmung zuteilt. Dann fügt sich alles von selber zusammen. Von allen Seiten ruft es: Ja! Jeder Wahrnehmung winkt eine andere zu. Jeder Zug, der sichtbar wird, bestätigt, was bereits erkannt ist. Die Interpretation ist evident. Auf solcher Evidenz beruht die Wahrheit unserer Wissenschaft (Staiger 1955: 155).

De la vaguedad de estas descripciones es imposible inferir, sin embargo, cómo el simple recurso al procedimiento del círculo hermenéutico y a la evidencia subjetiva puede impedir de por sí la arbitrariedad de la actividad comprensiva del sujeto y garantizar la 'verdad' de su interpretación, cuando, en realidad, es exclusivamente en la comprensión individual y en la habilidad personal del intérprete, o sea, en su "Gefühl", donde se fundamenta el criterio de la cientificidad de los resultados interpretativos obtenidos. El sujeto inicia su labor interpretativa como lector y al concluir su recepción personal, utilizando únicamente los datos que ésta le otorga y guiado por su particular criterio de evidencia y certeza, la erige en la interpretación adecuada 
del texto. Será, de este modo, tan sólo en la subjetividad de su propia recepción donde el intérprete fundamente, en suma, la pretendida verdad del sentido aprehendido.

Esta identificación que la interpretación hermenéutica efectúa entre el lector y el investigador y, consiguientemente, entre la recepción individual y la interpretación 'científica', es denominada por N. Groeben (1972: 137 y 143) "SubjektObjekt-Konfundierung". El intérprete, en tanto llega a equiparar su concretización individual con el significado textual, se constituye a un tiempo en sujeto (en calidad de intérprete) y en objeto (como lector) de la interpretación literaria. Por tal motivo difícilmente se le podrá atribuir un carácter propiamente científico al procedimiento hermenéutico: los resultados interpretativos no serían más que una opinión subjetiva. Las limitaciones del método intrínseco, a este respecto, son ostensibles si se trata de aplicar, a modo de ejemplo, al siguiente texto:

Der gallische Hahn hat jetzt zum zweiten Male gekräht, und auch in Deutschland wird es Tag. In entlegene Klöster, Schlösser, Hansestädte und dergleichen letzte Schlupfwinkel des Mittelalters flüchten sich die unheimlichen Schatten und Gespenster, die Sonnenstrahlen blitzen, wir reiben uns die Augen, das holde Licht dringt uns ins Herz, das wache Leben umrauscht uns, wir sind erstaunt, wir befragen einander: - Was taten wir in der vergangenen Nacht?

La interpretación de este texto, un fragmento de la obra de Heinrich Heine Einleitung zu Kahldorf über den Adel, (1968: 20) como también la de muchos otros, difícilmente puede reducirse a una lectura estrictamente inmanente que desestime el contexto histórico de su producción y las peculiaridades de la personalidad de su autor. En efecto, sólo si se desiste de una 'contemplación pura' y se consideran factores externos como las ideas sociopolíticas de Heine y el año 1831 como fecha de su producción, se podría reconocer en el texto una apología poética de la Revolución de Julio de 1830.

En definitiva, puede concluirse que como quiera que las diversas vertientes hermenéuticas adoptan un proceder interpretativo basado en la coincidencia del sujeto de la interpretación con el propio objeto de la misma, la interpretación hermenéutica se reduce a la realización de operaciones subjetivas que escapan tanto a cualquier iniciativa de control real y efectivo de su desarrollo como al intento de comprobación intersubjetiva de sus resultados. Precisamente este subjetivismo es la razón por la que el procedimiento comprensivo generado por la hermenéutica no puede ser considerado apto en cuanto método operacional que garantice resultados intersubjetivamente corroborables. De la comprensión en cuanto método existen tantas versiones diferentes como corrientes hermenéuticas, sin que ninguna alcance a configurarse como un método claro y definido susceptible de ser catalogado como científico. Las peculiaridades de la comprensión hermenéutica permiten, a lo sumo, conceptuarla como un procedimiento heurístico, o sea, no científico, válido, eso sí, para la formulación de hipótesis o conjeturas. 


\section{Entre el constructivismo y el sustancialismo: la crítica recepcional empírica}

Como alternativa al subjetivismo interpretativo de la hermenéutica y como solución a la permanente crisis metodológica, en las últimas décadas se ha tratado de desarrollar una fundamentación empírica de la crítica literaria. El objetivo primordial de dicha fundamentación es configurar los estudios literarios como una actividad perteneciente a una ciencia socioempírica de la comunicación, a fin de que la investigación literaria proceda según los criterios de las ciencias empíricas. En especial, ha sido N. Groeben quien ha sentado las bases teóricas más significativas para el esbozo de semejante modelo de una crítica literaria recepcional empírica9

Al objeto de superar la identificación hermenéutica del receptor con el investigador y poder alcanzar, de este modo, una separación precisa de las operaciones de explicación y de recopilación de datos, que garantice la imparcialidad de la interpretación literaria, Groeben (1972: 143) exige observar "das literarische Sender-Empfänger-System von außen". A tal efecto, todo proceso interpretativo que aspire a alcanzar unos resultados con validez intersubjetiva ha de delimitar con claridad la actividad subjetiva y emocional propia de la recepción, esto es, la concretización individual de la obra literaria, frente a la justificación racional y científica de esa recepción, o sea, frente al análisis interpretativo (Groeben 1972: 168). En opinión de Groeben, semejante delimitación sólo podrá ser realmente efectiva si las tareas de recepción e interpretación son atribuidas a distintos sujetos; es decir, si el intérprete, renunciando a interpretar su propia concretización emocional del texto, establece los datos destinados a servir de fundamento observacional a la interpretación a partir de la comprobación intersubjetiva en los receptores de sus concretizaciones individuales de la obra literaria (Groeben 1972: 168). La objetividad del proceso de recopilación de estos datos quedaría garantizada en virtud de la utilización de procedimientos metodológicos explícitos e intersubjetivos, propios de las ciencias sociales, como por ejemplo la paráfrasis, el análisis de contenidos, la asociación libre, el diferencial semántico o el cloze procedure.

Las distintas comprensiones/concretizaciones particulares de la materialidad textual realizadas por múltiples receptores, comprobadas y registradas por medio de la observación intersubjetiva, constituyen, en suma, el punto de partida y el objeto del análisis interpretativo. Éste, entendido como "die theoretische Konstruktion von Werksinn auf der Grundlage von Rezeptionsdaten" (Groeben 1980: 133), es decir, como descripción y explicación teórica de los datos recopilados intersubjetivamente, no se configurará, a la postre, como una operación propia del receptor, sino como una acción exclusiva del intérprete. El objeto del conocimiento (las concretizaciones del receptor) y su correspondiente sujeto (el intérprete) quedarían, de este modo, estrictamente separados.

De este modo, la concepción de crítica literaria recepcional empírica desarrollada por Groeben, al fijar un objeto temático de investigación constituido por la singula-

\footnotetext{
${ }^{9}$ A lo largo de sus numerosos estudios teórico-literarios, Groeben ha desarrollado y precisado su propuesta de una crítica recepcional empírica. Véase. a este respecto, en particular, GROEBEN (1979, 1980, 1981, 1982a, 1982b, 1987, 1989); GROEBEN / LANDWEHR (1991).
} 
ridad de las concretizaciones comprensivas de los lectores, pero también en tanto exige la estricta separación del intérprete y del receptor, va a invertir la relación subjetivización de la metodología / objetivización del ámbito de estudio, propia de la hermenéutica clásica, a favor de una objetivización de la metodología interpretativa. Es decir, el gran avance que supone la crítica recepcional empírica radica en la aplicación de una metodología científica en su actividad investigadora: el crítico empírico, partiendo de los múltiples significados individuales atribuidos al texto que le han puesto a disposición los receptores, está llamado a construir el sentido de la obra de forma teórica, el cual ya no puede considerarse como una simple especulación subjetiva, sino que, al estar basado en datos comprobados intersubjetivamente, ofrece garantías científicas: "Die Objektivität des empirischen Vorgehens liegt in der intersubjektiven, kontrolliert-systematischen Beobachtung der rezeptiven Bedeutungskonkretisationen literarischer Texte" (Groeben 1980: 12).

A fin de garantizar semejante objetividad, debe evitarse, sin embargo, que las operaciones cognoscitivas de asignación de significado efectuadas por los lectores sean analizadas en orden a las peculiaridades y procesos mentales del sujeto que las realice, o que incluso estos procesos sean identificados con el propio sentido de la obra. Semejante actitud conllevaría un retroceso al psicologismo, el cual propugna la eliminación de la materialidad textual. En cualquier caso, siempre ha de ser "die material-objektive Textdeskription" (Groeben 1972: 183), y no el receptor, lo que constituya la base material para la construcción del sentido de la obra literaria. Pues, como reitera Groeben (1979: 52, 1972: 171), los datos empíricos aportados por las recepciones, o sea, los "Konkretisationsdaten", de los que son inferidos el sentido y las características textuales, no son observaciones o datos sobre el lector, es decir, "Leserdaten", sino básicamente sobre el propio texto, esto es, se configuran únicamente como "Werkdaten". En el proceso teórico de la interpretación, el sujeto lector interviene como "Medium, über dessen Konkretisation sinnhafte Beobachtungsdaten des literarischen Werkes als Grundlage der literaturwissenschaftlichen Theorienbildung faßbar sind" (Groeben, 1972: 171).

La argumentación teórica explicitada por Groeben, por cuanto fundamenta la interpretación literaria en el análisis empírico de los distintos procesos de recepción desarrollados por múltiples lectores, asume tanto el concepto funcional del texto, tal como fue elaborado por la estética de la recepción a partir de las consideraciones de Ingarden y del estructuralismo de Praga, como, consecuentemente, las implicaciones metodológicas de él derivadas. Pero, por otra parte, Groeben no se contenta únicamente con desarrollar una metodología coherente con el concepto funcional del texto. Al objeto de otorgar garantías propiamente científicas a la labor del crítico literario, la metodología interpretativa de la crítica recepcional empírica no se limita a efectuar una recopilación de las diversas concretizaciones, controlada intersubjetivamente, y a establecer el sentido textual a partir de los elementos concordantes de las mismas. Una realización plena del programa teórico-literario desarrollado por Groeben comporta la inclusión de los datos observacionales registrados en un proceso de construcción y comprobación de hipótesis interpretativas. Es precisamente este aspecto el que garantiza eficazmente la sepa- 
ración clara y la diferenciación conceptual precisa entre las operaciones de recepción e interpretación: la recepción sería el proceso constitutivo de significado, la concretización textual, el objeto de la observación científica. La interpretación, en cambio, tiene como finalidad establecer construcciones teóricas que son comprobadas con la ayuda de los datos recepcionales observados (Groeben 1980: 133). El proceder empírico-científico atribuido al crítico literario consiste, en suma, según precisa Groeben rigiéndose por las consideraciones metateóricas de la filosofía analítica de la ciencia de corte empírico-positivista, pero también por las desarrolladas por el falsacionismo popperiano, en la formulación o construcción de hipótesis de una gran capacidad explicativa acerca del sentido textual ${ }^{10}$. Estas hipótesis interpretativas, para que en realidad adquieran la condición científica, deben ser contrastables y contrastadas intersubjetivamente, entendiéndose dicha contrastación como posibilidad de refutación en caso de que los datos empíricos, recogidos mediante la observación sistemática y controlada de las concretizaciones textuales, no coincidan con la construcción teórica. Pues, como propuso K. R. Popper (1935, 1965), las teorías únicamente podrán ser consideradas empíricas, si, en efecto, más que verificadas son falsables por los datos observados intersubjetivamente merced a un proceso deductivo.

Este procedimiento de comprobación de hipótesis supone una estricta separación entre el nivel propiamente observacional, por un lado, y la interpretación teórica, por otro; un hecho que comporta tanto la clara delimitación del sujeto frente al objeto del conocimiento como, asimismo, la dicotomización del lenguaje científico en un sublenguaje observacional y otro teórico. El establecimiento de la dicotomía teórico/observacional, por cuanto permite recurrir a datos no-teóricos (Groeben 1982b: 272-273), es considerada por Groeben de esencial importancia: sólo así, es decir, si los indicadores empíricos no se presentan relativizados ni se derivan de las hipótesis teóricas establecidas, y los procedimientos de observación y recogida de datos son independientes del observador, se podría garantizar que los enunciados teórico-interpretativos sean efectivamente refutados o, en el mejor de los casos, corroborados de manera imparcial y objetiva por los datos empíricos aportados por las concretizaciones de los receptores (Groeben 1979: 44, 1982b: 272 y ss.). Por ello, para que puedan cumplir eficazmente su función, se exige de los indicadores observacionales que hayan sido recogidos con independencia de toda construcción teórica y que sean capaces de ejercer de falsificadores potenciales de la hipótesis interpretativa.

Esta función de comprobación de hipótesis atribuida a la empiria es, además, absolutamente necesaria, dado que los términos teóricos, por ejemplo el "contenido" de un texto literario, o bien, el "horizonte de expectativas" de un grupo de

${ }^{10}$ Como ejemplo de formulación de hipótesis, Groeben ofrece la siguiente construcción teórica referida al aspecto formal del texto: "Der Text $\mathrm{T}$ hat in den Dimensionen der Bildstrukturen (Emblem, Topos, Metapher, Allegorie, Symbol etc.) und der Thematologie (Motiv, Charakter, Typus, Fabel, Thema, Idee, Mythos etc.) für die Lesergruppe LG die Bedeutung/den Sinn TB/TS" (GROEBEN 1982b: 278). 
lectores, son constructos elaborados por el sujeto intérprete que no designan fenómenos que se encuentren directamente en la realidad o que hagan referencia inmediata a ella. Más bien, los enunciados teóricos adquieren la relación con el mundo empírico sólo de manera indirecta a través de los correspondientes términos observacionales, por ejemplo, como expone Groeben, a partir de los significados textuales referentes al motivo o al tema, obtenidos mediante la utilización de un cuestionario, o bien, tomando como base aquellos significados aportados por las respuestas a una encuesta sobre las expectativas de un grupo de receptores respecto al cumplimiento o incumplimiento de determinadas normas literarias (Groeben 1982b: 273). Son estos indicadores empíricos, cuya peculiaridad es la de remitir inmediatamente a lo perceptible y que en consecuencia pueden ser comprobados intersubjetivamente, los que justifican y definen operacionalmente el sentido cognoscitivo, no especulativo y científico, de los constructos teóricos.

En definitiva, en un intento por conjugar el procedimiento inductivo de formulación de hipótesis, explicitado por R. Carnap, con el de su comprobación deductiva, conforme al criterio de falsabilidad propuesto por Popper, Groeben presenta dos fórmulas de actuación del crítico empírico en el transcurso de la interpretación literaria. Éste puede optar por determinar el sentido textual mediante su inferencia inductiva a partir de los múltiples datos observacionales aportados por los receptores, o bien, puede contrastar con esos mismos indicadores empíricos una construcción teórico-interpretativa previamente establecida con la finalidad de justificarla o refutarla de manera deductiva. Elija una u otra fórmula, el modelo hermenéutico de interpretación, aunque si bien no es completamente desestimado en esta concepción empírica de la crítica literaria, no se le ofrece al investigador como un método; antes al contrario, puede disponer de él simplemente de modo heurístico, es decir, como un medio para la generación intuitiva de hipótesis. Pues, como el mismo Groeben afirma, ya no se pregunta, como era el caso en la propuesta hermenéutica, acerca de la comprensión individual que corresponda a la obra, sino sobre la construcción teórica del sentido textual, o sea, acerca de la interpretación que se manifiesta adecuada en orden a los significados textuales o datos recepcionales que han sido constatados de manera intersubjetiva (Groeben 1982b: 276). En este sentido, siguiendo el modelo de comprobación de hipótesis desarrollado por la crítica recepcional empírica, los resultados obtenidos por la interpretación literaria, en cuanto construcción teórica del sentido textual, son considerados adecuados siempre y cuando, tras repetidos intentos, no hayan sido refutados vía deductiva por los datos empírico-recepcionales aportados por los lectores; es decir, si tras ser sometidos a prueba por medio de la contrastación con la experiencia no han podido ser falsados y, en consecuencia, su contenido informativo se manifiesta empíricamente consolidado (Groeben 1981: 18).

A este respecto, Groeben expresa su convencimiento de que su modelo sí permite dar solución de manera aceptable a uno de los problemas centrales que se le planteaba al proceder interpretativo de la hermenéutica: la cuestión de la adecuación de la recepción. Tanto más cuanto que los indicadores recepcionales configuran, a la postre, la instancia de la que depende la justificación de las hipótesis in- 
terpretativas. Ahora bien, si la adecuación de las manifestaciones o resultados del análisis interpretativo está supeditada a la corroboración de esos resultados mediante la contrastación empírica, la consolidación de su contenido informativo tan sólo podrá ser científicamente efectiva, evitándose así una contradictio in adiecto, a condición de que las instancias falsadoras, o sea, las recepciones textuales, hayan sido asimismo corroboradas, dado que la posibilidad de error también les afecta a ellas. Es concretamente en la búsqueda de una solución a esta cuestión, es decir, en la dilucidación del proceso de justificación de la recepción adecuada, donde el modelo de Groeben incurre, como ya le ocurrió a la hermenéutica clásica, en una grave incoherencia.

A fin de esclarecer esta problemática, Groeben recurre al establecimiento de una relación de legitimación entre lo que él denomina estructura material y objeti$v a$ del texto, existente con anterioridad e independencia a toda concretización del significado, y las concretizaciones realizadas por los receptores. "Für die Frage nach der Adäquanz der Textkonkretisation steht als Eingrenzungskriterium die Erhebung der materialen Textstruktur zur Verfügung" (Wolf / Groeben 1981: 39). El procedimiento metodológico a seguir estriba en un análisis empírico de esa relación, de manera que si se comprueban contradicciones entre la propia configuración material del texto y la estructura conceptual de la concretización ha de catalogarse la recepción como inadecuada. "Textrezeptionen sind durch den Rückgriff auf die material-objektive Textbeschreibung als inadäquat nachweisbar, wenn ein Widerspruch zwischen konkretisierter Textbedeutung und material-objektiver Textstruktur festzustellen ist“ (Groeben 1987: 96). Será así la compatibilidad con la estructura material del texto lo que determine la adecuación, o más concretamente, la no-inadecuación de la recepción, como recalca Groeben (1980: 142) en numerosas ocasiones: "Die Konkretisation literarischer Werke kann [...] nicht positiv als adäquat ausgezeichnet werden, sondern lediglich (vom negativen Pol her) als nicht-inadäquat!". Pues de acuerdo con el falibilismo popperiano, que al reafirmar el carácter hipotético de las construcciones teóricas estima que el conocimiento de lo que llamamos 'realidad objetiva' no se alcanza mediante una justificación positiva de las teorías, sino únicamente via negationes por la falsación y eliminación de las hipótesis que no superen la contrastación empírica (Popper 1935: 8, 19, 199, 212, 225 y 256 y ss.), Groeben asume esa relación de asimetría entre la verificabilidad y la falsabilidad de las hipótesis, y se sirve de ella para esclarecer la función que la materialidad textual desempeña en el proceso de comprobación de los datos recepcionales: el análisis material del texto no puede ratificar o confirmar positivamente una recepción, pero sí en cambio, ex negativo, puede refutarla y descartarla, o sea, falsarla definitivamente.

Se trate de la adecuación, o bien, de la no-inadecuación de la recepción, lo cierto es que esta diferenciación conceptual, o si se quiere metódica, en nada altera el hecho de que es en la posibilidad de constatación objetiva de la materialidad textual y en la supuesta relación de legitimación entre estructura material y sentido, donde el procedimiento metodológico de comprobación de hipótesis recepcionales, explicitado por Groeben, encuentra su fundamento. Pues, la estructura material 
del texto tendrá que ser la que en última instancia decida sobre el grado de aceptabilidad o verosimilitud de los significados y sentidos que se le han atribuido a esa misma estructura.

De este modo, la crítica recepcional empírica, una concepción teórico-literaria de marcado carácter constructivista, se ve obligada, en el momento de plantearse la dilucidación de la adecuación del proceso recepcional y a fin de garantizar la objetividad de la contrastación empírica e impedir la arbitrariedad en el proceso de elección o rechazo de las recepciones, a introducir la realidad textual como un marco objetivo y autónomo de referencia. Esta determinación, que es resultado de la influencia que sobre Groeben ejercen tanto el empirismo positivista como el falsacionismo popperiano, pero también el sustancialismo hermenéutico del que, a nuestro juicio, no consigue separarse del todo, va a suponer que sean los datos específicamente textuales, y no los aportados por el lector, el factor que determine unilateralmente la idoneidad de los resultados recepcionales.

En rigor, Groeben no logra desembarazarse por completo de los postulados sustancialistas y llega, en definitiva, a trasladar a otro nivel, concretamente al ámbito de la recepción, el problema axial de la hermenéutica clásica, esto es, la adecuada constatación del sentido fijo e invariable que supuestamente le es inherente a la obra literaria. Al objeto de evitar la arbitrariedad y asegurar la imparcialidad en el proceso recepcional, Groeben llega a reemplazar el constructivismo inicial de su modelo por un sustancialismo tácito. Precisamente por ello, y al sustentarse esta propuesta empírico-literaria en la posibilidad de un conocimiento objetivo de la realidad textual, su modelo deriva en la asunción, cuando menos implícitamente, del concepto ontológico e inmanente del texto propio de la hermenéutica. Pues cómo podría ejercer la materialidad textual de correctivo, o bien, de medida imparcial de comprobación de las concretizaciones del significado, si no se presumiera que éste ya está implantado en el texto de modo fijo e invariable con anterioridad a la actuación del lector. Únicamente bajo este supuesto se podría admitir que la materialidad textual es susceptible de legitimar el significado que se le ha otorgado.

La cuestión de si se ha de averiguar el sentido correcto o auténtico de un texto a partir de la evidencia subjetiva, como pretende la hermenéutica, o por el contrario si se ha de establecer a partir de los datos recepcionales de un grupo de lectores, como reclama la crítica recepcional empírica, es un planteamiento que estimamos inadecuado. Pues en ambos casos se presupone la identidad semántica de la obra. En rigor, el sentido textual tan sólo tiene razón de ser en relación con unos receptores determinados y en un contexto preciso, y podría variar tan pronto cambien los receptores y el contexto (Steinmetz 1987: 139).

Consideramos, en suma, que las contradicciones del modelo propuesto por Groeben tienen su origen en las insuficiencias del fundamento metateórico elegido, o sea, en la falta de reconocimiento de la labor ampliamente constructiva del sujeto de la cognición y en la asunción de un concepto positivista de lo empírico, por otra parte ya superado en el seno de la teoría de la ciencia. Pues, como ha demostrado con claridad la propia teoría de la ciencia, los criterios teórico-científicos del empirismo positivista de Carnap, pero también los del racionalismo crítico de 
Popper, contradicen el proceder real de la ciencia, al no tener en cuenta que los indicadores o datos observacionales que otorgan legitimidad o ilegitimidad a las teorías no son independientes ni están libres de condicionalidad teórica. Estos indicadores no tienen validez ni son adecuados o inadecuados en términos absolutos, sino sólo con relación al sistema teórico o modelo de realidad al que en última instancia pertenecen. En consecuencia, la dependencia teórica de los datos recepcionales muestra lo inadecuado que resulta cualquier intento de legitimar la actividad recepcional recurriendo a la materialidad objetiva del texto. El texto no puede constituirse en una instancia objetiva de control que ejerza de medida imparcial de comprobación de los resultados interpretativos, como tampoco en una instancia que legitime por sí misma a la propia recepción.

En definitiva, la actividad eminentemente constructiva del receptor, y no sólo del intérprete, obliga a proponer una superación explícita del sustancialismo y, en consecuencia, a plantear una modificación del modelo de crítica recepcional empírica desarrollado por Groeben, lo que llevará, a continuación, a profundizar en sus planteamientos renovadores.

\section{Comprensión e interpretación literarias}

En términos generales, la comprensión textual puede considerarse como un conjunto de operaciones y estrategias mentales, realizadas y aplicadas por un sistema cognitivo -el receptor- en distintos niveles de procesamiento de los estímulos textuales: silábico, léxico, oracional y textual. Al comprender un texto, el receptor, tras activar su sistema de conocimientos lingüísticos, construye representaciones fonológicas, léxicas, sintácticas y semánticas, en cuyo resultado final, la comprensión, intervienen, además de los datos textuales, el contexto situativo y su conocimiento del mundo. En ese proceso de construcción significativa, el receptor reconoce las letras, transforma las letras en sonidos, construye una representación fonológica de las palabras, activa los diversos significados de éstas, selecciona un significado adecuado al cotexto y contexto, asigna a cada palabra un valor sintáctico, construye el significado y el sentido de las oraciones, realiza inferencias, integra los sentidos particulares y constituye el sentido global del texto, etcétera. La mayoría de estas operaciones se efectúan muy rápidamente y el receptor ni siquiera es consciente de ellas.

Desde un enfoque interactivo, que se asume aquí (Maldonado Alemán 2003: 165 y ss.), la comprensión textual, y en concreto la lectora, a la que nos circunscribimos en adelante, configura un proceso activo de procesamiento de información que se desarrolla sobre la base de la interacción texto-lector, siguiendo dos tipos de operaciones específicas: por un lado, operaciones ascendentes, de abajo-arriba (bottom-up), del texto al lector, que son motivadas por la estructura lingüísticomaterial de los datos textuales; y, por otro, operaciones descendentes, de arribaabajo (top-down), que atañen a las estructuras cognitivas que el lector asigna a las señales lingüísticas percibidas. Ambos procesos se desarrollan conjuntamente, en 
una constante interacción, si bien las operaciones descendentes son determinantes en el proceso global de comprensión. En esa interacción intervienen por parte del lector cuando menos su saber, intenciones, deseos e intereses, así como también la información que éste deriva de la situación de comprensión; por parte del texto su estructura material, es decir, sus unidades grafemáticas y sintácticas.

La lectura es una operación guiada conceptualmente de condición inferencial. A diferencia de la hipótesis fundamental de los modelos autónomos (Maldonado Alemán 2003: 156 y ss.), según la cual la comprensión se inicia con la percepción y elaboración primera de unidades textuales individuales, continúa con su transformación sucesiva en proposiciones elementales (microproposiciones) y su posterior integración en complejos proposicionales cada vez más amplios (macroproposiciones), hasta llegar finalmente a la comprensión del sentido global del texto, se entiende que, en rigor, el proceso de constitución significativa no comienza con la lectura del texto, con la simple percepción de su estructura lingüístico-material, con su descripción y especificación pura y neutra, pues estas operaciones nunca son inmediatas, sino más bien con un conjunto de conocimientos estructurados que aparece constituido por conceptos, esquemas, marcos referenciales, modelos, sistemas, etcétera, almacenados en la memoria del receptor. Estos conocimientos previos conforman, con anterioridad al inicio de la actividad de comprensión, las estrategias de recepción, motivación, intencionalidad, expectativas, etcétera, del lector.

Básicamente, la actividad lectora aparece determinada por el contexto situativo que todo receptor elabora, explícita o implícitamente, al enfrentarse a un texto, al que vincula sus expectativas previas a la comprensión. Estas expectativas atañen a la función social y comunicativa del texto, y permiten anticipar un contenido determinado e incluso ciertas formulaciones estereotipadas o un estilo específico, como se puede comprobar fácilmente, por ejemplo, en el caso de una misiva privada, un telegrama, la primera página de un periódico o un poema.

El proceso comprensivo se evidencia, de este modo, como un fenómeno transaccional que, además de los datos textuales, integra un amplio sistema de presuposiciones del receptor compuesto por su saber, intenciones, deseos e intereses, así como por las características de la situación de comprensión (Huber 2008: 53 y ss.). El complejo sistema mental del lector estructura sus expectativas sobre el texto y, especialmente, sus acciones de recepción, y crea, previamente a la lectura, un amplio contexto de acciones cognitivas en el que se dan diferentes posibilidades de comprensión.

Por consiguiente, en el proceso de lectura, el receptor no actúa como un simple mecanismo pasivo-reactivo, sino ante todo como un elemento cognitivamente activo y constitutivo de sentido (Sichelschmidt / Günther / Rickheit 1992: 117; Kuhangel 2003: 21 y ss.). Debido a ello, la comprensión textual no es, primariamente, una actividad dirigida por los signos lingüísticos, o sea, un proceso de reconstrucción, en cuyo transcurso un texto concreto (input) conduce necesariamente a un sentido determinado (output). La actividad lectora no consiste en reflejar especularmente el texto a partir de operaciones de traducción de las oraciones a proposiciones; tampoco constituye una simple operación de traslación de informaciones lingüísticas a una representación cognitiva. Más bien, configura un proceso 
dinámico que desemboca en la construcción de una estructura conceptual compleja, en la constitución de un mundo coherente de ideas de desigual relevancia y valor, en el que éstas se ponen en relación, se organizan y jerarquizan. En lo esencial, la comprensión es resultado de un proceso activo y continuado de construcción de sentido, que se desencadena en el ámbito cognitivo del receptor ciertamente a raíz de la percepción de la estructura lingüístico-material de un texto, pero que inevitablemente está motivado, dirigido y organizado por las expectativas e intenciones particulares del receptor, por sus conceptos y saber individual sobre el mundo. Así pues, para comprender un texto no es suficiente el conocimiento del lenguaje o saber usar un código lingüístico; es necesario, además, un conocimiento situativo y del mundo. Son estas últimas estructuras de saber, y no propiamente el conocimiento lingüístico, el factor determinante en el proceso comprensivo.

Partiendo del principio de la unidad indisoluble entre conciencia y actividad lingüística (Hörmann 1976: 501), se constata que la comprensión lectora es un fenómeno primariamente cognitivo que resulta del desarrollo de determinados procesos mentales de construcción, de la constitución concreta de un modelo mental del texto, cuya representación, por su estructura y función, es bien distinta a la representación proposicional: mientras que una representación proposicional es un conjunto de unidades discretas de información que manifiestan un carácter digital, un modelo mental es una representación global y directa de condición analógica.

Al comenzar el proceso de lectura, tras los primeros impulsos textuales, el lector establece unas hipótesis iniciales acerca del significado textual, o sea, construye un modelo mental del texto, aún poco especificado, pero con una estructuración completa. El lector valora ese modelo de acuerdo con sus criterios, expectativas e intenciones particulares, y en un marco individual de coherencia y de constancia de sentido. En el transcurso del proceso de comprensión irá completando, precisando y, dado el caso, modificando el modelo mental inicial a través de numerosos subprocesos secuenciales y merced al uso cíclico de un procedimiento de prueba y error manifiestamente intencional: el receptor examina repetidamente la coherencia interna del modelo mental construido, comprobando la compatibilidad de los datos textuales actualizados con su sistema de presuposiciones y el contexto situativo, hasta conseguir un resultado que le satisfaga subjetivamente. Primordial en ese proceso no es para el receptor la elaboración de la información textual, sino la construcción mental de un modelo particularmente coherente del texto, o sea, de su sentido y de su función. La representación cognitiva finalmente obtenida, que sólo es una entre otras posibles, resultará así de una compleja actividad de integración y construcción, desarrollada a modo de proceso intencional centrado en el conocimiento y el saber del sujeto y guiado por las estrategias que éste utiliza. En el transcurso de la comprensión, las operaciones de inferencia no se efectúan en la base textual, en el nivel lingüístico-proposicional, sino estrictamente en la misma representación mental del texto, a fin de precisarla y completarla.

En definitiva, la comprensión textual, en cuanto fenómeno que resulta de la construcción creativa, emotiva e intencional de una representación significativa del texto en el ámbito cognitivo del receptor, surge con el establecimiento de una 
continuidad de sentido: el resultado comprensivo se configura como el conjunto de las relaciones de sentido que el receptor asigna a un texto, a partir de la integración de la materialidad textual y de las características de la situación de comunicación en sus estructuras de saber, o sea, como resultado último de la constitución y especificación de un modelo mental del texto. Si se presentan discrepancias entre la constelación de conceptos sugerida por el texto y por la situación comunicativa, y el saber del receptor, es decir, en la manera cómo esos conceptos se relacionan en su conciencia, entonces el receptor no podrá establecer ninguna continuidad significativa, y el texto, simplemente, no tendrá sentido para él. La comprensión textual se configura, así, en lo fundamental, como una acción cognitiva y comunicativa compleja, compuesta de numerosas operaciones realizadas intencionalmente por un sujeto con motivo de un texto, a modo de proceso interactivo, en un contexto social y en una situación determinada, y de acuerdo con un sistema de presuposiciones.

En el caso de un texto considerado literario, esas operaciones son parte constitutiva de un proceso de comprensión literaria en cuanto fenómeno complejo, en el que un componente esencial es el saber que el lector posee acerca del texto en cuestión y sobre la manera cómo ha de proceder con él para comprenderlo literariamente de modo adecuado. Ese saber está formado por factores duraderos y ocasionales, por elementos intraliterarios y extraliterarios, y por componentes supraindividuales, individuales y situativos (Beilfuß 1987: 31; Kuganhel 2003: 22 y ss.). En lo fundamental, ese saber se ha ido formando en el proceso de socialización literaria del lector y depende de su condición biográfica y situación social e histórica (Wünsch 1984: 897). Concretamente, ese saber incluye un saber lingüístico -el saber sobre las regularidades fonológicas, morfológicas, sintácticas, semánticas y pragmáticas de una lengua-, un saber sobre el mundo -el saber general sobre objetos, situaciones, sucesos, series de acciones, convenciones, papeles sociales, etcétera-, un saber sobre géneros, normas y valores literarios, los conocimientos que sobre el autor posee el lector, sus recuerdos de otras lecturas, la curiosidad y la motivación provocadas por el título del texto, el saber sobre operaciones cognitivas y estrategias a utilizar para la superación de posibles dificultades en el proceso de comprensión, etcétera. El saber que posee el lector estructura sus expectativas sobre el texto y, en especial, sus operaciones de recepción, y crea, previamente a la lectura, un amplio contexto de acciones cognitivas en el que se dan diferentes posibilidades de comprensión.

En definitiva, las estructuras de saber desempeñan en el proceso de comprensión literaria una doble función: por un lado, al dirigir y posibilitar las acciones, expectativas y competencias individuales de los lectores, permiten que éstos obtengan resultados comprensivos subjetivamente satisfactorios; por otro, gracias a su componente intersubjetivo, las estructuras de saber otorgan a las experiencias e intenciones individuales de los lectores una legitimación social y posibilitan que éstas sean comunicadas a otros receptores.

En la comprensión literaria de un texto ejerce una influencia decisiva las características contextuales de la situación de recepción, por ejemplo la predisposición de los receptores a leer un texto de modo literario (Meutsch 1987: 156). Gracias al con- 
texto, con frecuencia un receptor ya sabe antes de leer las primeras líneas o incluso el título del texto, si puede o debe leerlo como texto literario. Las peculiaridades del contexto de recepción permiten activar los esquemas convencionalizados para la lectura literaria que el lector ha adquirido socialmente, lo que posibilita una acción de recepción determinada. Estas convenciones dirigen el proceso de recepción e influyen decisivamente en la determinación del receptor de leer el texto de manera literaria. En ese caso, el lector llega a comprender literariamente un texto de modo apropiado si sigue las convenciones literarias vigentes en su grupo social. En el lenguaje empleado por la psicolingüística y la lingüística del texto estas convenciones corresponden a las estrategias que dirigen y modifican los procesos descendentes, de arriba-abajo (top-down), orientados por los esquemas.

Desde esta perspectiva, la diferencia entre una recepción literaria y otra no literaria depende de las peculiaridades de las operaciones de recepción, o sea, de la especificidad de la actividad lectora, y no, al menos primariamente, de las características del texto. Así, dado que un contexto literario de recepción conduce, normalmente, a una recepción literaria de los textos, un mismo texto puede ser considerado unas veces como literario y otras como no literario, al cambiar las características contextuales (Halász 1993: 209 y 222 y ss.). Por ello, la recepción literaria no debe concebirse como el acto de comprender la literatura, sino como un proceso de comprensión literaria de los textos. O sea, no se comprenden textos literarios, sino que se comprenden determinados textos de manera literaria.

La comprensión literaria se configura, en definitiva, como un proceso de construcción activa, creativa, emotiva e intencional de una representación significativa del texto en el ámbito cognitivo del receptor. Se trata de un proceso global, mental, flexible y cíclico de construcción de sentido, compuesto de diferentes procesos parciales, en los que el texto aparece como un factor más junto a otros factores sociales y psíquicos. La comprensión se desarrolla como proceso interactivo que integra operaciones orientadas por los datos textuales y también operaciones dirigidas conceptualmente. Ese proceso tiende, sobre todo, al establecimiento de la constancia de sentido y se muestra determinado por el saber, planes, intenciones, finalidad, deseos, intereses y estados afectivos del sujeto lector, así como también por las características contextuales de la situación de comprensión, en las que intervienen las convenciones literarias vigentes en un momento dado. La actividad comprensiva aparece dirigida por las estrategias de recepción utilizadas por el receptor. Éste elabora esas estrategias en relación con la organización y presentación de la materialidad textual y en correspondencia con la especificidad de la finalidad y del contexto de lectura.

El texto participa en el proceso de su comprensión a través de su materialidad lingüística, la cual es percibida como un conjunto de datos, valorada e integrada cognitivamente en las estructuras de saber del sujeto lector. La existencia de la materialidad textual es, lógicamente, una condición imprescindible para que al texto se le pueda atribuir sentido y pueda distinguirse un texto de otro; pero esa materialidad, en rigor, no especifica ni pronostica las características de ese sentido, ni obliga al lector a la elaboración de un sentido determinado. Por lo general, sólo 
en lo que respecta a la descripción de los componentes puramente formales y estructurales del texto y a la constitución del significado convencional de sus elementos, se puede decir que el texto actúa como un factor relevante, siempre y cuando el receptor disponga de los conocimientos necesarios para ello, por ejemplo de una lengua natural. Pero esa relevancia no es determinante en el proceso de construcción y atribución de sentido. De las dimensiones que intervienen en ese proceso -texto, receptor y situación comunicativa-, es el horizonte cognitivo del individuo en el que se integran las señales textuales percibidas y las características contextuales de la situación de comprensión la instancia decisiva. Los datos textuales sólo pueden ser significativos si son puestos en relación con un saber extratextual y una situación comunicativa, a los que se suman formando una unidad de sentido. Por ello las peculiaridades de la materialidad textual no determinan la construcción del sentido otorgado al texto. Aunque el texto es sin duda un factor a tener en cuenta en todo proceso receptivo, su función queda limitada a orientar, pero no a determinar, la actividad receptiva del lector. En este sentido se puede afirmar que el texto interviene en el proceso de su comprensión según cómo el sujeto receptor lo percibe, estructura y valora cognitivamente, esto es, con arreglo a la integración que los receptores efectúan de los componentes textuales percibidos en sus estructuras de saber y en las características de la situación de comprensión.

En virtud de estas consideraciones, la interpretación de un texto literario no debe concebirse como la constatación del sentido correcto del texto, o bien, como el descubrimiento de la verdadera intención del autor. Exceptuando el análisis formal de las estructuras fonológicas, fonéticas, morfológicas, sintácticas, léxicas, narrativas, métricas o estilísticas de un texto, o bien, cuestiones relativas a su historia de transmisión o de edición, los aspectos semánticos y estéticos atribuidos a las obras literarias deberán ponerse en relación con los receptores e intérpretes y con su particular contexto de recepción e interpretación ${ }^{11}$.

Normalmente, en las descripciones puramente estructurales de un texto y en la atribución del significado convencional de sus elementos lingüísticos -por ejemplo, el de los términos "Prinz", "Stadt", "Hof", "Graf", "Täler", "Landgut", "Vermählung", "Verbrechen", etcétera, en Emilia Galotti de Gotthold Ephraim Lessing- no suelen alcanzarse resultados dispares, siempre y cuando esas descripciones y atribuciones se realicen siguiendo las convenciones y estrategias propias de una lengua natural. El problema surge cuando partiendo de los resultados obtenidos por el análisis formal se le asigna un sentido a la materialidad textual -en el caso de Emilia Galotti, por ejemplo, "la muerte de Emilia es el triunfo del ideal burgués de virtud frente a la arbitrariedad e inmoralidad del tirano"- o se efectúan aserciones valorativas -"la muerte de Emilia a manos del padre es una solución positiva del conflicto"-, explicaciones histórico-contextuales -"el drama es un reflejo del desmesurado despotismo cortesano y del afán de emancipación de la burguesía de la época"-, afirmaciones sobre la función de las estructuras -"la es-

${ }^{11}$ Véase a este respecto los análisis de distintos modelos interpretativos efectuados por SPREE (1995). Véase también KuHANGel (2003: 29 y ss.). 
tructura rectilínea del drama y la rígida causalidad del desarrollo de la acción expresan que lo que acontece en el mundo está sometido a un orden preestablecido y no es producto del azar o de la casualidad"-, etcétera. En el momento en el que se integran las características formales y los diferentes significados convencionales en una estructura de sentido coherente y se construye un mundo textual, entonces normalmente los intérpretes obtienen resultados muy dispares, dada la multiplicidad y la manifiesta e inevitable subjetividad de los contextos de sentido que aquéllos establecen para poder comprender e interpretar el texto. Y buena prueba de ello son las variadas y a veces contradictorias interpretaciones que se han realizado de Emilia Galotti.

Ello es así, porque lo que es válido para la recepción de la obra literaria, también lo es para su interpretación. La interpretación está íntimamente vinculada a la comprensión. De hecho sólo se puede interpretar un texto que efectivamente se haya comprendido con anterioridad. En la interpretación intervienen prácticamente las mismas variables que en la comprensión:

- el texto,

- el intérprete,

- la situación de interpretación,

- la finalidad de la interpretación,

- el sentido interpretativo,

- el destinatario.

Normalmente, los intérpretes suelen desempeñar su cometido interpretativo en el marco de un determinado contexto institucional, al que pertenecen, por ejemplo, en calidad de estudiosos de la literatura, críticos literarios, profesores, educadores, etcétera. El contexto institucional lo componen, en ese caso, la crítica literaria académica, la universidad y otras instituciones educativas, editoriales, revistas especializadas, medios de comunicación de masas (periódicos, revistas, radio o televisión), etcétera. Estas instituciones ejercen su influencia sobre la interpretación y la condicionan, regulando, directa o indirectamente, las normas interpretativas, al sancionar algunas y rechazar otras. Las instituciones establecen lo que puede o debe ser interpretado, así como el modo particular de hacerlo. Las instituciones autorizan maneras de interpretar, sancionan qué modelos interpretativos son aceptados y conservados durante un largo periodo de tiempo. Las instituciones otorgan, de esta manera, legitimidad a la interpretación o se la quitan, según sus necesidades e intereses, y confieren valor y privilegio a los textos, lo que implica la preservación y afianzamiento de un determinado repertorio canonizado (Kermode 1979: 111-112; Even-Zohar 1997: 49-51). Ya por esa razón los modelos interpretativos legitimados constituyen variables históricas: una determinada época considerará necesario un determinado tipo de interpretación, otra, por el contrario, podrá optar por otro.

La influencia de las instituciones es tan determinante que un cambio del contexto institucional comporta, por lo general, una modificación en el modo de inter- 
pretación y en sus resultados. Un crítico literario puede interpretar un mismo texto de manera diferente según el contexto en el que inserte su interpretación, que puede ser un congreso, una revista especializada, el suplemento cultural de un periódico o una clase de literatura (Strube 1993: 131 y ss.). El intérprete, al elaborar su interpretación, tendrá en cuenta los conocimientos, necesidades e intereses de los destinatarios. Y, en función precisamente de esos destinatarios y del contexto de presentación de los resultados interpretativos, podrá perseguir distintos intereses y fijar finalidades diversas. Así, la interpretación que dirija, por ejemplo, a un grupo de especialistas en un congreso cumplirá una finalidad diferente a la interpretación del mismo texto que exponga a unos estudiantes en una clase de literatura. Y los intereses subyacentes que persiga con esa actividad también pueden variar. Pueden abarcar desde la construcción coherente del sentido comunicativo del texto, hasta la reconstrucción de procesos históricos, la explicitación de ideas y valores vigentes en la sociedad del autor, la aclaración de problemas o circunstancias del presente, la explicación del valor estético que atribuye al texto o la indagación acerca del inconsciente del autor.

La interpretación, al igual que ocurre en la comprensión, sitúa el texto en un contexto de sentido, que permita comprenderlo e interpretarlo. Es decir, el mundo textual o estructura coherente que resulta de la actividad interpretativa supone la utilización del principio de constancia de sentido y la constitución previa de un marco referencial que permita estructurar y sistematizar con congruencia las características formales y significados convencionales atribuidos a los elementos textuales. El sentido verdadero o auténtico de un texto, o su supuesto valor estético inherente, sólo se podrían averiguar si efectivamente se lograra establecer una referencia objetiva o intersubjetiva fuera del ámbito cognitivo del sujeto, que sirviera de medida imparcial de comprobación. Sin embargo, en la constitución del marco de referencia participan, consciente o inconscientemente, el sistema de presuposiciones, los intereses, las necesidades, la finalidad, los conocimientos, las facultades, las intenciones, etcétera, del intérprete, así como también el modelo de realidad y las convenciones y modelos teóricos vigentes en su grupo social. Cualquier acción de interpretación presupone siempre al intérprete y un contexto, y específicamente los criterios y conceptos teórico-literarios, poetológicos y semánticos que aquél utiliza, que son los factores de los que depende directamente la interpretación textual. O sea, en todo caso el marco referencial necesario para la atribución de sentido o valor estético a un texto literario se encontrará fuera del texto y dentro del sistema cognitivo del intérprete, y no será posible que el propio texto se constituya en la instancia que decida si el marco referencial elegido y el sentido o valor que de él se deriven son los correctos.

En un sentido amplio, al igual que otras formas de conocimiento, también el interpretativo está determinado de manera explícita o implícita por teorías (Pilz 2007: 19). La actividad interpretativa no parte de la percepción pura y simple, pues ésta nunca es inmediata, sino más bien de un punto de vista concreto, de un problema previo que se pretende resolver, de una teoría subyacente que dirige la interpretación. Siempre será lo teórico, y no la percepción o la observación, lo pri- 
mordial en todo proceso interpretativo, sin que se dé la posibilidad de una interpretación, descripción o explicación de la dimensión textual pura o neutra.

En todo proceso interpretativo las teorías actúan como un conjunto de supuestos, reglas y modelos centrales y distintivos, referidos a un determinado tipo de fenómenos, que sirven de fundamento para la descripción, explicación y valoración de la dimensión material del texto. Las teorías actúan como una herramienta conceptual que, a raíz de un problema determinado, permite obtener un conocimiento sistematizado sobre un aspecto concreto de la práctica literaria. La validez de una teoría reside en su poder explicativo y en la capacidad para resolver las cuestiones planteadas, y no en un supuesto acercamiento a la verdad o realidad óntica. Como nos enseñan disciplinas como la filosofía de la ciencia o la biología cognitiva, no se da una relación de correspondencia entre el objeto de conocimiento y el objeto real, existente con independencia del sujeto de la cognición. Nunca el objeto de conocimiento es externo a las teorías; antes al contrario, es constituido por ellas mismas. Con la ayuda de teorías implícitas o explícitas, que pueden presentarse como conceptos, esquemas, marcos referenciales, modelos, sistemas, etcétera, el sujeto intérprete, observa, describe, analiza o explica el fenómeno literario, sistematizando y estructurando sus experiencias.

La primacía de lo teórico tiene validez en doble sentido: las teorías no son sólo constitutivas del conocimiento, sino también del ámbito de experiencia al que se refiere ese conocimiento. Por un lado, determinan el modo específico de experimentar los fenómenos y, por otro, delimitan los fenómenos que van a ser objeto de conocimiento, es decir, seleccionan de todos los hechos potencialmente observables aquéllos que son relevantes en relación con la cuestión teórica planteada. De ello se deduce que las teorías no encuentran su aplicación primera en el proceso de investigación o explicación de un determinado fenómeno, sino más bien en el proceso de su constitución: el dominio de investigación tiene que ser primeramente constituido a la luz de una teoría, para poder ser posteriormente investigado o explicado también con la ayuda de teorías. Describir y explicar un determinado fenómeno significa, por tanto, insertarlo en una teoría en cuyo marco cobra sentido. O lo que es lo mismo, con la elección de una determinada teoría literaria no sólo se determina, en el proceso de interpretación, lo que va a ser considerado un texto literario (el dominio u objeto de investigación), sino también el modo cómo aparecerá ese texto, o sea, la perspectiva o aspectos bajo los cuales se considerará el texto (fundamento epistemológico), así como la manera de actuación del intérprete con el texto, esto es, su forma de argumentación y explicación (fundamento metodológico), e incluso los procedimientos concretos de análisis e investigación que el sujeto utilice (fundamento metódico). Ello explica que los resultados obtenidos por la interpretación dependan del concepto de literatura que se utilice, del marco teórico elegido, de la metodología que se siga en cuanto expresión concreta de ese marco teórico y de los métodos aplicados; lo que obliga a evitar la confusión que surge con frecuencia entre lo que pueda ser la realidad literaria con la noción que se tenga de esa realidad. 
Dada la primacía de lo teórico, de la actividad interpretativa deberá exigirse que supere el procedimiento espontáneo y emocional que caracteriza a las acciones de recepción y que explicite y sistematice con claridad las teorías, conceptos y métodos que sirven de fundamento para la obtención de un determinado conocimiento. O sea, la interpretación, partiendo de normas o de reglas de procedimiento fijadas de antemano, deberá actuar de un modo sistemático, riguroso y preciso que permita abandonar la espontaneidad propia de la fase de recepción y posibilite la justificación racional de la comprensión individual del texto.

En cualquier caso, ante la inexistencia de un marco objetivo de referencia y dada la falta de una relación de legitimación entre texto e interpretación, los criterios de valoración de las hipótesis interpretativas no serán los de verdad, falsedad o evidencia, sino los de argumentación plausible y coherente, congruencia, concordancia o ausencia de contradicciones, compleción, especificidad, relevancia, oportunidad e innovación, entre otros. Más que de la constatación del sentido atemporal y único de un texto, la corroboración de una interpretación es consecuencia de una operación de convencimiento social: una interpretación logra finalmente imponerse no porque el texto la legítima y demuestra su verdad, sino gracias a su aceptación social por consenso. El grado de aceptación de la interpretación dependerá de su conformidad con las necesidades, convenciones, valores, intereses y normas de valoración de las instituciones literarias de una sociedad dada en un momento determinado.

Con ello, la interpretación se configura como una actividad constructiva y productiva, caracterizada por el empleo de una argumentación plausible y persuasiva que pretende alcanzar para sus hipótesis la aceptación por consenso, y no como una actividad que se distinga por su objetividad ni por satisfacer criterios científicos. Esto en realidad no es un inconveniente, sino una gran ventaja: la parcialidad de la atribución de sentido preserva al texto de ser usurpado unilateralmente y libera a la actividad interpretativa de actitudes dogmáticas y de la propensión normativa, garantizándole uno de sus mayores atractivos: mostrar otras posibilidades innovadoras de lectura y ayudar, aunque sin intención preceptiva, al lector profano en la realización de su propia recepción. Así y todo, es necesario diferenciar entre el intérprete profesional o especialista y el lector normal. Pues mientras que el simple lector establece su contexto interpretativo de modo espontáneo y no pretende realizar una interpretación sistemática o rigurosa del texto, el intérprete profesional, por lo general, dirige sus resultados interpretativos a un colectivo de especialistas a los que pretende convencer y a veces hasta criticar, por lo que se esforzará en elaborar una argumentación plausible y bien estructurada.

\section{Referencias bibliográficas}

AcostA, L. A., «El procedimiento hermenéutico como modelo de conocimiento en la actual ciencia literaria», Studia Philologica Salmanticensia 2 (1978), 25-51.

AcostA, L. A., El lector y la obra. Teoría de la recepción literaria. Madrid: Gredos 1989. 
BeILfuß, W., Der literarische Rezeptionsprozeß. Ein Modell. Frankfurt am Main, et al.: Peter Lang 1987.

BIRUS, H., «Zwischen den Zeiten. Friedrich Schleiermacher als Klassiker der neuzeitlichen Hermeneutik», en: BIRUS, H. (ed.), Hermeneutische Positionen. Schleiermacher Dilthey - Heidegger - Gadamer. Göttingen: Vandenhoeck \& Ruprecht 1982, 15-58.

BRACKERT, H. / STÜCKRATH, J. (eds.), Literaturwissenschaft. Ein Grundkurs. Reinbek: Rowohlt 1992.

Brenner, P. J., Das Problem der Interpretation. Eine Einführung in die Grundlagen der Literaturwissenschaft. Tübingen: Niemeyer 1998.

BrinKMANN, H., Mittelalterliche Hermeneutik. Tübingen: Niemeyer 1980.

CONRADY, K. O., Literatur und Germanistik als Herausforderung, Frankfurt am Main: Suhrkamp 1974.

DiLtheY, W., Abhandlungen zur Grundlegung der Geisteswissenschaften, en: DILTHEY, W., Gesammelte Schriften, vol. 5: Die geistige Welt. Einleitung in die Philosophie des Lebens. 1. Hälfte. Ed. de G. Misch. Stuttgart / Göttingen: Teubner / Vandenhoeck \& Ruprecht, 8 a ed., 1990 [1900].

DiLthey, W., Der Aufbau der geschichtlichen Welt in den Geisteswissenschaften, en: DiltheY, W., Gesammelte Schriften, vol. 7. Ed. de B. Groethuysen. Stuttgart / Göttingen: Teubner / Vandenhoeck \& Ruprecht, $7^{\mathrm{a}}$ ed., 1979 [1910].

EBELING, G., «Hermeneutik», en: Die Religion in Geschichte und Gegenwart. Handwörterbuch für Theologie und Religionswissenschaft, vol. 3. Ed. de K. Galling. Tübingen: J.C.B. Mohr, $3^{a}$ ed., 1959, 242-262.

EVEN-ZOHAR, I., «Factores y dependencias en la cultura. Una revisión de la teoría de los polisistemas», en IgLESIAS SANTOS, M., Teoría de los polisistemas. Madrid: Arco/Libros 1999 [1997], 23-52.

GADAMER, H.-G., Wahrheit und Methode. Grundzüge einer philosophischen Hermeneutik, en: Gadamer, H.-G., Gesammelte Werke, vol. 1: Hermeneutik I. Tübingen: J.C.B. Mohr, 6 ed., 1990 [1960].

GADAMER, H.-G., Interpretationen, en: GADAMER, H.-G., Kleine Schriften, vol. 2. Tübingen: J.B.C. Mohr 1967.

GADAMER, H.-G., «Klassische und philosophische Hermeneutik», en: GADAMER, H.-G., Gesammelte Werke, vol. 2: Hermeneutik II. Tübingen: J.C.B. Mohr 1986, 92-117.

GARrido Gallardo, M. A. et al., La crisis de la literariedad. Madrid: Taurus 1987.

GROEBEN, N., Literaturpsychologie. Literaturwissenschaft zwischen Hermeneutik und Empirie. Stuttgart: Kohlhammer 1972.

GROEBEN, N., «Zur Relevanz empirischer Konkretisationserhebungen für die Literaturwissenschaft», en: SCHMIDT, S. J. (ed.), Empirie in Literatur- und Kunstwissenschaft. München: Fink 1979, 43-81.

Groeben, N., Rezeptionsforschung als empirische Literaturwissenschaft. Paradigmadurch Methodendiskussion an Untersuchungsbeispielen. Tübingen: Narr 1980.

GROEBEN, N., «Forschungsfragen und Untersuchungsplan», en: GROEBEN, N. (ed.), Rezeption und Interpretation. Ein interdisziplinärer Versuch am Beispiel der 'Hansenkatastrophe'von Robert Musil. Tübingen: Narr 1981, 9-26.

GROEBEN, N., Leserpsychologie: Textverständnis - Textverständlichkeit. Münster: Aschendorff 1982a.

Groeben, N., «Empirische Literaturwissenschaft», en: HART, D. / GeBHART, P. (eds.), Erkenntnis der Literatur. Theorien, Konzepte, Methoden der Literaturwissenschaft. Stuttgart: Metzler 1982b, 266-297. 
GroEBEN, N., «Verstehen, Erklären, Bewerten in einer empirischen Literaturwissenschaft», en: IBSCH / SCHRAM (eds.) 1987, 65-106.

Groeben, N., «Das Konzept der Text-Leser-Interaktion in der Empirischen Literaturwissenschaft», SPIEL 8/2 (1989), 255-273.

GROEBEN, N. / LANDWEHR, J., «Empirische Literaturpsychologie (1980-1990) und die Sozialgeschichte der Literatur: ein problemstrukturierender Überblick», Internationales Archiv für Sozialgeschichte der deutschen Literatur 16/2 (1991), 143-235.

HalÁsz, L., Dem Leser auf der Spur. Literarisches Lesen als Forschen und Entdecken. Zur Sozialpsychologie des literarischen Verstehens. Braunschweig / Wiesbaden: Vieweg 1993.

HeIDEGgER, M., Sein und Zeit. Tübingen: Niemeyer 1957.

HeINE, H., Werke, vol. IV: Schriften über Deutschland. Ed. de H. SCHANZE. Frankfurt am Main: Insel 1968.

HEYDEBRAND, R. VON, «Literarische Wertung», en: KANZOG / MASSER (eds.) 1984, 828-871.

HöRmann, H., Meinen und Verstehen. Grundzüge einer psychologischen Semantik. Frankfurt am Main: Suhrkamp $3^{\mathrm{a}}$ ed. 1988 [1976].

HuBER, F., Durch Lesen sich selbst verstehen. Zum Verhältnis von Literatur und Identitätsbildung. Bielefeld: transcript 2008.

IBSCH, E./ SchrAM, D. H. (eds.), Rezeptionsforschung zwischen Hermeneutik und Empirik. Amsterdamer Beiträge zur neueren Germanistik 23. Amsterdam: Rodopi 1987.

JAEGER, H.-E. H., «Studien zur Frühgeschichte der Hermeneutik», Archiv für Begriffsgeschichte 18 (1974), 35-84.

JAPP, U., «Hermeneutik», en: BRACKERT / STÜCKRATH (eds.) 1992, 581-593.

KANZOG, K . / MASSER, A. (eds.), Reallexikon der deutschen Literaturgeschichte, vol. IV. Berlin / New York: de Gruyter, $2^{\mathrm{a}}$ ed., 1984.

KERMODE, F., «El control institucional de la interpretación», en: Sullá, E. (ed.), El canon literario. Madrid: Arco/Libros 1998 [1979], 91-112.

KuHANGEL, S., Der labyrinthische Text. Literarische Offenheit und die Rolle des Lesers. Wiesbaden: Deutscher Universitäts-Verlag 2003.

LAU, V., Erzählen und Verstehen. Historische Perspektiven der Hermeneutik. Göttingen: Königshausen \& Neumann 1999.

MALdONADO AlemÁn, M., Texto y comunicación. Madrid: Fundamentos 2003.

MEuTsCH, D., «Wie 'entsteht' ein verständlicher Text? Einflüsse literarischer und nicht literarischer Kontexte auf zielspezifische Verstehensprozesse», Zeitschrift für Literaturwissenschaft und Linguistik (LiLi) 55 (1984), 86-112.

Meutsch, D., Literatur verstehen. Eine empirische Studie. Braunschweig / Wiesbaden: Vieweg 1987.

PILZ, D., Krisengeschöpfe. Zur Theorie und Methodologie der Objektiven Hermeneutik. Wiesbaden: Deutsche Universitäts-Verlag 2007.

PopPer, K. R., Logik der Forschung. Tübingen: J.C.B. Mohr, 6a ed., 1976 [1935].

POPPER, K. R., Conjectures and refutations. The growth of scientific knowledge, London: Routledge and Kegan Paul, $2^{\text {a }}$ ed., 1965.

Pozuelo Yvancos, J. M. a, Teoría del lenguaje literario. Madrid: Cátedra 1988.

Pugliese, A. O., «Von der Hermeneutik zur Text-, Kontext- und Intertextanalyse. Eine Reflexion über literaturwissenschaftliche Methodologie und Methodik», en: NolTINGHauff, I. / Schulze, J. (eds.), Das fremde Wort. Studien zur Interdependenz von Texten. Festschrift für Karl Mauerer zum 60. Geburtstag. Amsterdam: B. R. Grüner 1988, 17-50. 
RUSCH, G., «Literatur in der Gesellschaft», en: SCHMIDT, S. J. (ed.), Literaturwissenschaft und Systemtheorie. Positionen, Kontroversen, Perspektiven. Opladen: Westdeutscher Verlag 1993, 170-193.

Rusterholz, P., «Hermeneutik», en: Arnold, H. L. / Sinemus, V. (eds.), Grundzüge der Literatur- und Sprachwissenschaft, vol. I: Literaturwissenschaft. München: dtv, $9^{a}$ ed., 1990, 89-105.

SCHLEIERMACHER, F. D. E., Hermeneutik und Kritik. Ed. de M. Frank. Frankfurt am Main: Suhrkamp, 4a ed., 1990 [1977].

SICHELSCHMIDT, L. / GÜNTHER, U. / RICKHEIT, G., «Input Wort: Befunde zur inkrementellen Textverarbeitung», Zeitschrift für Literaturwissenschaft und Linguistik (LiLi) 86 (1992), 116-141.

SPREE, A., Kritik der Interpretation. Analytische Untersuchungen zu interpretationskritischen Literaturtheorien. Paderborn et al.: Schöningh 1995.

STAIGER, E., Die Zeit als Einbildungskraft des Dichters. Untersuchungen zu Gedichten von Brentano, Goethe und Keller. Zürich: Atlantis 1953.

STAIGER, E., «Die Kunst der Interpretation», en: EnDERS, H. (ed.), Die Werkinterpretation. Darmstadt: Wissenschaftliche Buchgesellschaft, $2^{\mathrm{a}}$ ed., 1978 [1955], 146-168.

STEINMETZ, H., «Literaturwissenschaftliche Interpretation?», en: IBSCH / SCHRAM (eds.) $1987,137-154$.

STEINMETZ, H., «Sinnfestlegung und Auslegungsvielfalt», en: BRACKERT / STÜCKRATH (eds.) 1992, 475-490.

Strube, W., Analytische Philosophie der Literaturwissenschaft. Untersuchungen zur literaturwissenschaftlichen Definition, Klassifikation, Interpretation und Textbewertung. Paderborn: Schöningh 1993.

SzONDI, P., Einführung in die literarische Hermeneutik. Ed. de J. Bollack y H. Stierlin. Frankfurt am Main: Suhrkamp 1975.

WOLFF, R. / GROEBEN, N., «Zur Empirisierung hermeneutischer Verfahren in der Literaturwissenschaft. Möglichkeiten und Grenzen», en: KREUZER, H. / VIEHOFF, R. (eds.), Literaturwissenschaft und empirische Methoden. Eine Einführung in aktuelle Projekte, Zeitschrift für Literaturwissenschaft und Linguistik (LiLi), Beiheft 12. Göttingen: Vandenhoeck \& Ruprecht 1981, 27-51.

WÜNSCH, M., «Wirkung und Rezeption», en: KANZOG / MASSER (eds.) 1984, 894-919. 